\title{
THE URBAN PLANNER'S GUIDE TO COWORKING: A CASE STUDY OF TORONTO, ONTARIO
}

\author{
by \\ Zibby Petch \\ Bachelor of Civil Engineering, McMaster University, 2011 \\ A Major Research Paper \\ presented to Ryerson University \\ in partial fulfillment of the requirements for the degree of \\ Master of Planning \\ in \\ Urban Development
}

Toronto, Ontario, Canada, 2015

(c) Zibby Petch 2015 


\section{Author's Declaration for Electronic Submission of a MRP}

I hereby declare that I am the sole author of this MRP. This is a true copy of the MRP, including any required final revisions.

I authorize Ryerson University to lend this MRP to other institutions or individuals for the purpose of scholarly research

I further authorize Ryerson University to reproduce this MRP by photocopying or by other means, in total or in part, at the request of other institutions or individuals for the purpose of scholarly research.

I understand that my MRP may be made electronically available to the public. 


\title{
THE URBAN PLANNER'S GUIDE TO COWORKING: A CASE STUDY OF TORONTO, ONTARIO
}

\author{
(C) Zibby Petch, 2015 \\ Master of Planning \\ in \\ Urban Development \\ Ryerson University
}

\begin{abstract}
This paper describes exploratory research carried out to examine coworking, an emerging phenomenon of shared, collaborative work spaces, using a case study of the City of Toronto, from the perspective of urban planners and policy-makers. The research is premised on the belief that, as planners, being connected to the pulse of the city and documenting emerging trends is a critical component of our work. The research uses qualitative techniques, including interviews with coworkers and coworking site owner-operators to explore coworking specifically, to understand the experiences of coworkers, to begin to consider the potential implications of coworking sites on larger city systems, and to examine the relationship between the coworking site, the coworking community, and the surrounding neighbourhood. Ultimately, the research provides future directions for research, in order to inform recommendations about the potential role for public policy and planning intervention in the coworking industry.
\end{abstract}

Key words: Coworking; planning; public policy; sharing economy; creative competitiveness; Toronto. 


\section{Acknowledgements}

Many thanks to all of the participants in this research - your enthusiasm for coworking was both refreshing and infectious.

Thank you to my supervisor, Dr. Jaclene Begley, for her kind words of support, as well as feedback throughout the process. Thank you also to my second reader, Dr. Pamela Robinson, for her astute comments on my draft. 


\section{Table of Contents}

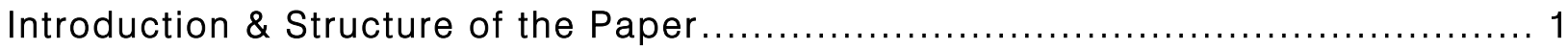

PART I - Setting the Context: Coworking \& Emerging Trends in Cities ............... 3

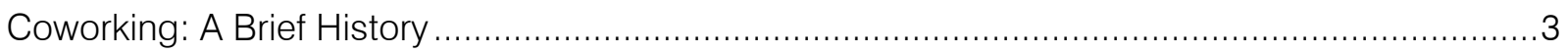

Sharing Spaces: Coworking \& The Sharing Economy .....................................................

Creativity \& Knowledge: The New Currencies ................................................................. 7

The Standardization of Non-Standard: Growth in Independent and Precarious Work .................9

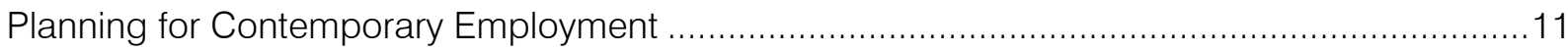

PART II - By the Books: The Literature on Coworking ........................... 15

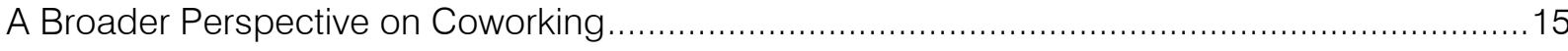

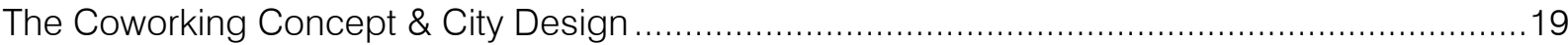

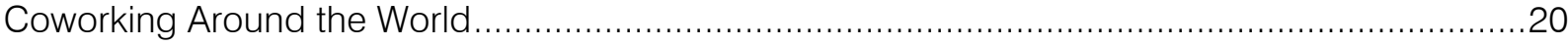

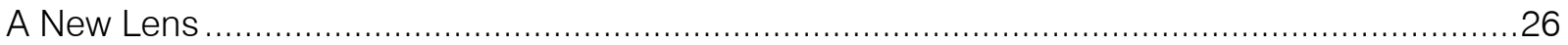

PART III - The Toronto Experience: A Qualitative Study .........................27

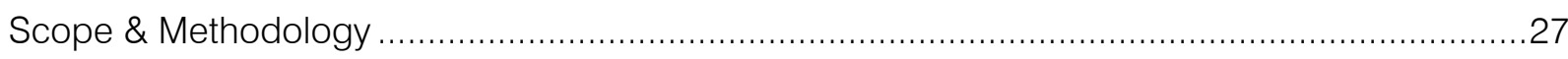

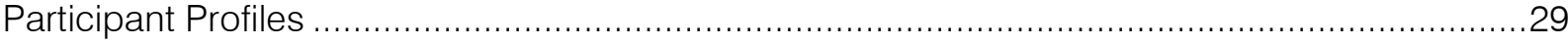

Laying the Groundwork: Understanding the Coworking Experience ....................................30

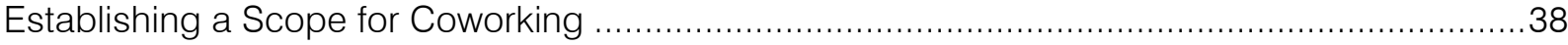

Coworking in the City: Exploring the Impacts .................................................................... 42

Is there a Role for Planning and Public Policy in Coworking? ..............................................47

PART IV - Conclusions \& Areas for Future Study ............................. 51

Appendix A - Survey Interview Questions ...................................... 53

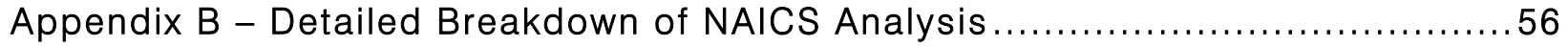

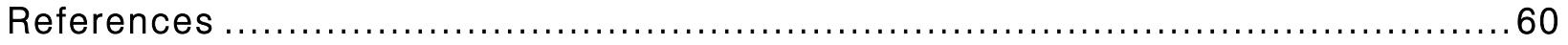




\section{List of Figures}

Figure 1 - Relative growth of coworking as a search term over time .................................. 3

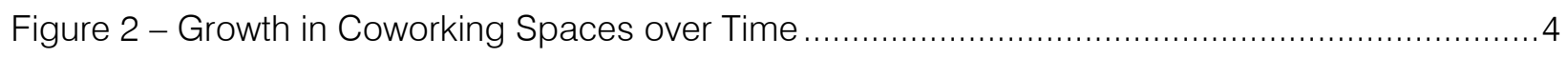

Figure 3 - Hierarchy of Planning Tools \& Policies............................................................ 12

Figure 4 - Coworking spaces as "third places"; From Moriset (2014) .......................................15

Figure 5 - Characteristic comparison between cluster and coworking space ..........................17

Figure 7 - The Good Neighbours Configuration of Coworking developed by Spinuzzi (2012).......22

Figure 8 - The Good Partners Configuration of Coworking developed by Spinuzzi (2012) ...........23

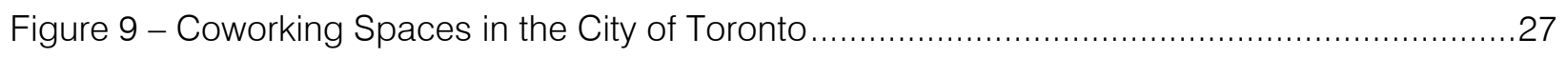

Figure 10 - Themes: Advantages of Coworking from Case Studies ......................................31

Figure 11 - Benefits of Coworking: The Toronto Experience .................................................. 32 


\section{Introduction \& Structure of the Paper}

This paper describes exploratory research carried out to examine coworking, an emerging phenomenon of shared, collaborative work spaces, using a case study of the City of Toronto, particularly from the perspective of urban planners and policy-makers.

The study addresses the following key research questions:

- What are the experiences of coworkers in the City of Toronto?

- What are the potential implications of coworking sites on larger city systems, both in terms of physical and social infrastructure?

- What is the relationship between the coworking site, the coworking community and the surrounding neighbourhood?

- What role (if any) emerges for public policy in the development and operation of coworking sites?

The paper is divided into four distinct parts:

- PART I: Setting the Context - This section of the paper provides an overview of the basic concepts that inform subsequent stages of the study. A brief overview of coworking is provided and examined as a phenomenon emerging in parallel with three larger trends governing cities: the shift to a knowledge economy and the growing importance of the 'creative class', the rise of the sharing economy, and a growth in precarious employment. These three trends are shown to relate to each other, and coworking spaces emerge as a physical manifestation of the resulting shifts in the way that employment, and the economy, unfolds in the twenty-first century. Finally, a discussion on the role of planners in the context of employment, generally, as well as coworking more specifically, provides a basis for the successive sections of the paper.

- PART II: Literature Review - The section of the paper provides a detailed examination of the limited academic literature relating to coworking, specifically focusing on case studies in other cities. In addition, examples from the literature are identified that provide additional evidence of the role of the three trends identified in Part I, and their connection to coworking. 
- PART III: Qualitative Study - This section of the paper presents the research study undertaken to examine coworking in the City of Toronto. The methodology, scope and limitations of the study are discussed, along with study results and findings. Significant themes and areas of emphasis emerging from the interviews are discussed in terms of implications for future research and policy. Specific roles for both economic development and planning are teased apart in order to separate the functions of the two groups.

- PART IV: Conclusions \& Areas for Future Study - Based on the analysis of qualitative results and the literature review, areas for future research are identified. 


\section{PART I - Setting the Context: Coworking \& Emerging Trends in Cities}

\section{Coworking: A Brief History}

Coworking, both the term as it used today and the practice, emerged just about ten years ago, in 2005. In the past ten years, coworking has grown exponentially in familiarity and use - becoming just one example of the rapidly changing landscape of the economy. Physically, these spaces present themselves as facilities with a combination of shared desks spaces, designated desks and often, private offices located within the larger facility. In addition to desk space, shared amenities such as storage, boardrooms, printers, photocopiers, scanners, kitchens, coffee machines, and even recreational facilities are frequently present. Some facilities offer specialized amenities, depending on the specific membership of the coworking site such as machinery, 3D printers or data storage.

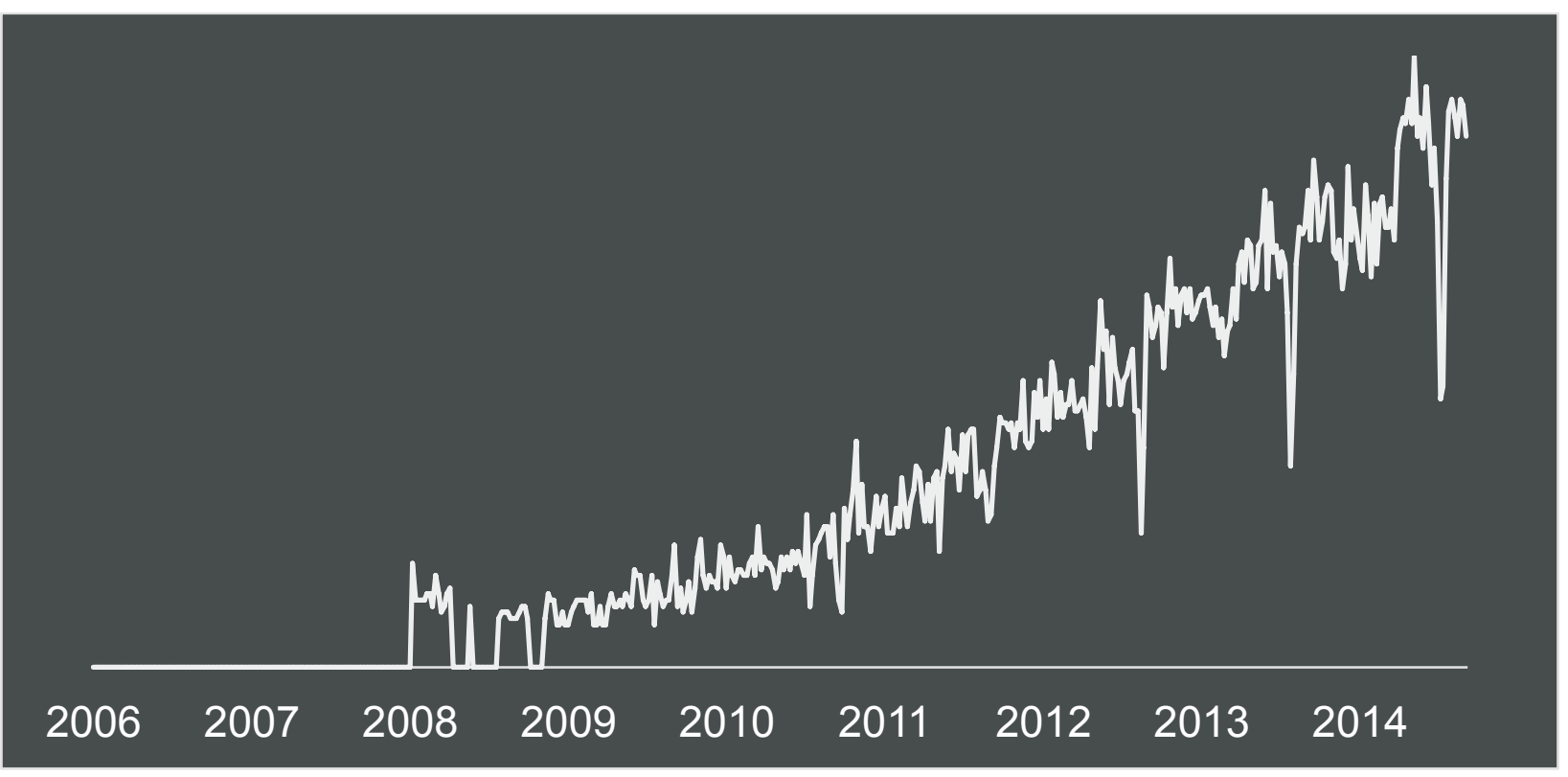

Figure 1 - Relative growth of coworking as a search term over time Source: Google Trends

It is important to distinguish coworking from other shared working environments for the purposes of this research. Coworking, as defined by the community, is not considered to be the same as virtual offices, executive centres, incubators or others models of shared space. The coworking community is defined by a series of values that have emerged over time: openness, community, accessibility, sustainability, and collaboration ("The Values of Open Coworking", n.d.). With these tenets, and in the way these spaces operate, coworking spaces move firmly beyond simply 
'spaces for rent'. For example, the membership of most coworking spaces is curated - members are vetted and selected to meet a number of criteria. In some cases they are selected to provide a mix (or similarity) of industries, but more importantly they must be looking for, and prepared to engage with, the community. These characteristics define the so-called 'genuine' coworking spaces that are they object of research for this study. Other shared spaces exist and may have similar or dissimilar operating environments, however coworking differentiates itself with the focus on community first, and the space as a way to facilitate collaboration.

So how did the concept spread so rapidly? And where did it all begin? In 2005, Brad Neuberg was searching for a place to work that would combine the freedom he appreciated from working for himself, with the community and structure of his previous role at a tech start-up company (Botsman \& Rogers, 2010). Ultimately, this led to a collaboration with two other self-employed technology-focused peers in San Francisco, who began to rent and share a space, Spiral Muse, a few days a week. The term coworking as applied to a collaborative workplace emerged, succeeding the '9 to 5 group' (Deskmag, 2010). Soon, the idea spread, and other self-employed entrepreneurs began to drop by, hoping to rent the space by the day or week. Ultimately, the concept was such a success that he opened the first formal coworking space in North America, the Hat Factory in San Francisco, in 2006 (Botsman \& Rogers, 2010).

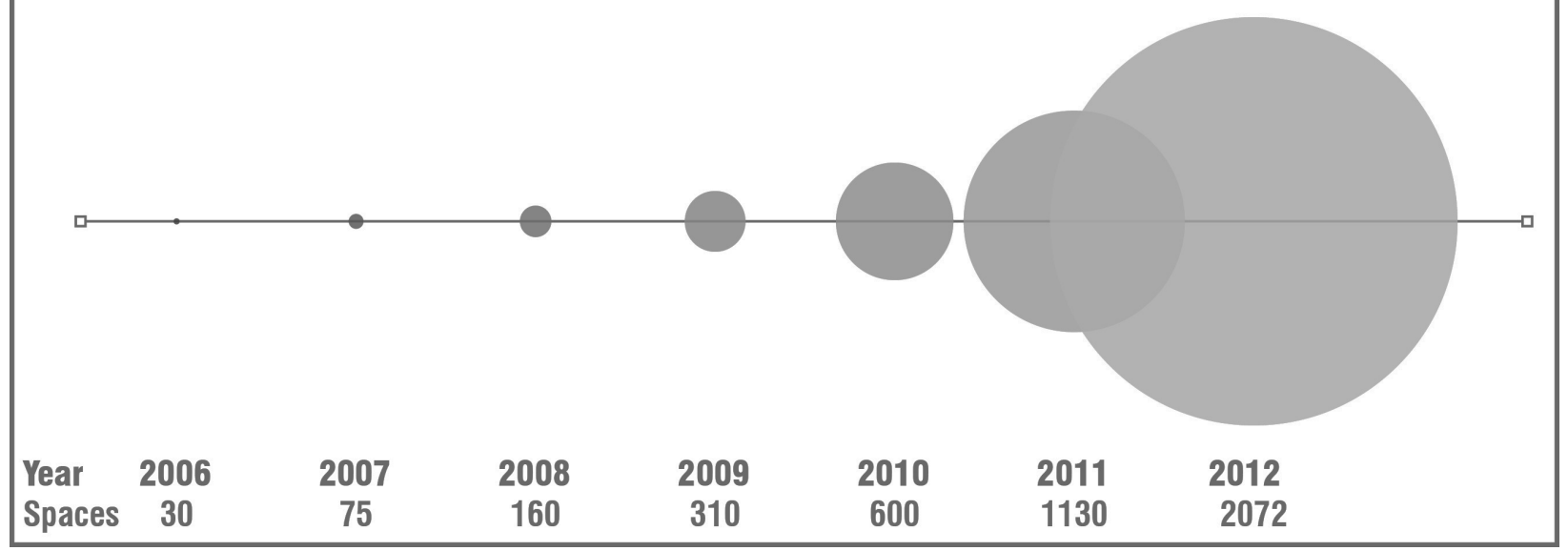

Figure 2 - Growth in Coworking Spaces over Time

Developed based on Data from the Deskmag Annual Coworking Survey (2012 \& 2013)

Growth in coworking since 2005 has occurred exponentially. It estimated that the number of coworking spaces globally has grown from about 30 in 2006 to over 2000 in 2012, experiencing more than 100\% growth annually (Deskmag, 2012 \& Deskmag, 2013). As with any other phenomenon, the growth of coworking can be seen to occur in concert with many larger shifts in 
the provision of goods and service, employment, and on a larger scale, cities. These movements are occurring on a global scale, impacting the way our cities operate and shifting the forms of employment over time. Since this study specifically focuses on coworking in the larger context of the city, it is important to acknowledge the role of these larger movements occurring along with the emergence of coworking.

\section{Sharing Spaces: Coworking \& The Sharing Economy}

"The fact is that our commerce, not to mention our social lives, has always depended on sharing" - (Gansky, 2010, p. 2)

The sharing economy can be broadly defined as the collection of business models that mark a significant shift from modern consumerism to a focus on collaborative consumption. In some ways, this economy draws on many historical notions of the market, which can include bartering or trading, and a focus on the use rather than the object. In modern times, however, "the sharing and collaboration are happening in ways and at a scale never before possible, creating a culture and economy of what's mine is yours" (Botsman \& Rogers, 2010. p. xv).

The sharing economy is no longer considered to be an emerging trend - instead it has arrived full force as an established ideology and business model. As Gansky (2010) puts it: "the sharing economy has moved from a quiet purr to a global attention-grabbing roar" (p. 165). With increasing awareness of the ecological impact of rampant consumerism and the inefficiencies associated with traditional business models, a shift to collaborative consumption is increasingly being recognized as a way forward. Indeed, as Matzler, Veider \& Kathan (2015) suggest, "the speed of growth with which sharing systems have spread suggests that the sharing economy might represent a serious threat to established industries" (p. 72).

Botsman \& Rogers (2010) formulate three categories of collaborative consumption within the sharing economy:

- Product Service Systems - in which users switch to paying for "the benefit of a product what it does for them - without needing to own the product outright" (p. 71) (e.g. carsharing)

- Redistribution Markets - in which the emphasis is on redistributing unused, unnecessary or underutilized resources to a customer who is in need of them (e.g. large-scale clothing swap websites) 
- Collaborative Lifestyles - which includes like-minded people "banding together to share and exchange less tangible assets such as time, space, skills and money, what we call collaborative lifestyles" (p. 73) (e.g. Trade Schools which run on a barter system - classes are taught on various subjects in exchange for currencies set by the teacher, for example baked goods or art materials)

Clearly, coworking is most directly related to 'collaborative lifestyles', since people form a community where they exchange ideas in a collaborative space. Coworkers share both tangible (space, printers, amenities, etc.) and less concrete (expertise, contacts) resources in a minieconomy. This trend is even being acknowledged specifically in the context of office real estate, as suggested by the annual Emerging Trends in Real Estate ${ }^{\circledR}$ report published by ULI \& PwC. The 2015 report suggests that:

The rise of the sharing economy, finding success with the millennial generation, which is very comfortable sharing rather than owning, is already having a disruptive effect...The office property type, particularly the segment serving smaller tenants, could be turned upside down by the advent of landlords offering collaborative and shared-office locations, as well as lessees renting out unused conference rooms by the hour or day of office space. This, in fact, is already a fairly familiar business model both in office incubators and in the business suites business (PwC \& ULI, 2014, p. 32).

Identifying and exploring the rise of the sharing economy provides an important framework that casts the development of coworking sites as a logical evolution from privatized, individual spaces to shared and collaborative centres. With increasing acceptance and recognition of a large-scale shift to collaboration, coworking is likely to experience a similar progression from fringe activity to mainstream strategy. As Botsman \& Rogers (2010) suggest, "all of these behaviours, personal stories, social theories, and business examples pointed to an emerging socioeconomic groundswell; the old stigmatized C's associated with coming together and 'sharing' cooperatives, collectives, and communes - are being refreshed and reinvented into appealing and valuable forms of collaboration and community." (p. vx).

Of course, the transformative nature of the new sharing economy would not be possible without certain preconditions. Specifically, innovative delivery models, including advancements in information technology, new conceptions of what work can be, and an emphasis on creativity as the primary mode of problem-solving are driving the massive shifts of the sharing economy. The emergence of the creative knowledge workers, and the maturing millennials, are driving growth in 
the sharing economy. Accordingly, it is important to explore the emphasis on creativity as it relates to larger shift in cities, including the sharing economy.

\section{Creativity \& Knowledge: The New Currencies}

"Innovation - the heart of the knowledge economy - is fundamentally social." - (Gladwell, 2000, para. 6)

Richard Florida's (2002) seminal work, The Rise of the Creative Class, documented and theorized the emergence of a particular subset of the labour force whose work drives innovation in cities. As member of the Creative Class, they "engage in complex problem solving that involves a great deal of independent judgement and requires high levels of education or human capital" (Florida, 2012, p. 8). Although Florida's specific definition of the creative class has received critique, the connection between the creative class and the knowledge economy seems clear. We live in a world in which "economic success is increasingly based on upon the effective utilisation of intangible assets such as knowledge, skills and innovative potential as the key resource for competitive advantage. The term 'knowledge economy' is used to describe this emerging economic structure" (ESRC, 2005 as cited in Brinkley, 2006, p. 4).

Similarly to the sharing economy, discussions about the knowledge economy emphasize the pace and speed at which the phenomenon is occurring. As Brinkley (2006) suggests, "the economy has always been driven by knowledge leading to innovation and technical change and knowledge based institutions have helped store and share knowledge for centuries. What we see today is essentially more of the same but operating on a bigger scale and at a faster pace" (p. 5).

So what are the implications of the knowledge economy for cities competing on a global scale? One of the most important shifts is the growing importance of place - the need for a city to attract and retain knowledge workers in order to thrive. Polèse argues that in considering the relative attractiveness of city centres, "the crucial variables are not land prices and wages or even labor relations-although they do matter-but rather the capacity to nurture, hold, and attract young entrepreneurs and professionals. Lifestyle issues, urban planning, and local social policies will undoubtedly continue to occupy center stage in 'big' places" (Polèse, 2010, p. 13). Similarly, Moriset (2014) suggests, "in the context of a globalized economy and increasing competition, creative individuals and innovative industries have been identified as key drivers of sustainable economic growth and prosperity" (p. 3). 
The need to attract and retain workers is a function both of liveability and economy - people want to live in a world-class city with amenities, and because they want to live there, they also want to work there. There is a tipping point - there must be a certain number of like-minded individuals in an area for it to remain attractive, and similarly so for productivity. For this reason, the size of the city is often, although not always, an important factor in retaining these workers. Polèse (2010) introduces the idea of his seven pillars of agglomeration - a way of capturing how the size of a city is related to its production and wealth capacity. The fourth pillar, 'The Need for Proximity', speaks to the emerging importance of location in the context of an economy that is increasingly based on specialized knowledge:

It is almost impossible to quantify the true impact of being in a place where industry ideas and information float 'as it were in the air.' The evidence suggests that the benefits of clustering are even greater today than they were a century ago. Why should this be so in the age of the Internet and the cell phone? If information and ideas can be sent over large distances at almost no cost, why is it still so important to be near people? The first part of the answer is simple: advanced economies require more complex information than a century ago. In today's knowledge economy, information, ideas, and know-how have become the primary rare resource. (Polèse, 2010, p. 39)

However, just as the rise of the knowledge economy has increased the importance of these types of workers, it has also impacted the workplace in a way that tends to alienate employees from their work life. One example is the emergence of 'lone eagles', workers "who can live and work anywhere, primarily because of advances in telecomputing technologies" (Young, 1997 in Moriset, 2014, p. 4). Florida (2012) similarly suggests that the creative class is "a relatively mobile class...much more concentrated in some cities and metro areas than in others" (p.11). Gotvassli (2012) explores the impact that the knowledge economy may have on workers in the new economy. He suggests "the development that has been sketched here - from an industrial society to a learning society - can mean that the whole of our Western industrial society is in the midst of a massive anti-standardization of the workplace" (p. 178). For example (Løwendahl, 1999 as cited in Gotvassli, 2012) suggests that these developments can influence the workplace in the following ways:

- "Neutral offices... produce little sense of belonging and identity" (p. 179)

- "Variable working hours and workplaces lead to people not knowing who is whom or who one is likely to meet" (p. 179)

- "It can be difficult to establish loyalty in organizations that employ many workers on a shortterm basis" (p. 179) 
The creative workforce then, would appear to be both suffering from a growing dissatisfaction with the workplace, and an increasing mobility - which could be a dangerous combination for corporations and cities that fail to address these issues. This increasing importance of place and proximity points to a potentially important role for the coworking movement. The idea that technological innovation and the rise of the knowledge economy has simultaneously created a mobile workforce, and then, startlingly, increased the importance of space is an interesting and important dichotomy for understanding the role of these spaces in the competitiveness of city regions.

The Standardization of Non-Standard: Growth in Independent and Precarious Work "Far and away the best prize that life offers is the chance to work hard at work worth doing." - Theodore Roosevelt

Over the last 20 years or so, there has been increasing attention paid to the issue of precarious employment. This type of employment typically is contract or part-time in nature, with limited health benefits, minimal access to unions and a higher degree of uncertainty with respect to future employment. As the Poverty and Employment Precarity in Southern Ontario (PEPSO) research group (2013) summarizes: "social scientists adopted the term 'precarity' to describe states of employment that do not have the security or benefits enjoyed in more traditional employment relationships. These precarious employment relationships are becoming the 'new normal' for our workforce." (PEPSO, 2013, p. 4). Of course, growing concern has been voiced about this trend since employment precarity is linked with significant concerns about wellbeing. While coworking has been heavily lauded for its role in supporting individuals in non-traditional employment, it must be considered at least partially as symptomatic, or representative of an increase in contract work and self-employment, which may reflect an undesirable outcome.

PEPSO (2013) found that within the Toronto CMA, "the number of people who describe their job as temporary increased by 40\% between 1997 and 2011" (2013, p. 16). Moreover, "across Canada, the category of 'self-employed without employees' increased almost 45\% between 1989 and 2007" (p. 2). Clearly, these trends cannot be ignored. However, in the context of coworking it may be challenging to determine the difference between those who choose a non-traditional form of employment and those who are forced into precarious employment. PEPSO acknowledges the difficulty in separating these groups: 
While it is true that some of the self-employed are innovators and wealth creators, many in this category are simply in a disguised form of employment without the benefits associated with standard employment. They may be dependent on a single client for all of their work, receiving direction on how to perform that work just as an employee would. Even for those who are not in a disguised employment relationship, being self-employed without any employees can be a precarious way to earn a living. (2013, p. 17)

Conflicting research suggests that push versus pull factors play into the rise in entrepreneurship and contract work. As Manser \& Picot (1999) suggest:

Not surprisingly, considerable attention has been paid in recent years to selfemployment in Canada, especially to workers' reasons for choosing this option. Have they been pushed by lack of full-time paid jobs or pulled by the positive benefits of self-employment?

Of course, the demographics of the worker may provide some clues as to the motivation for working in this manner. A study of independent workers in the US found the greatest concerns about the future lie with millennials:

Adult Millennials ${ }^{1}$ (ages 21-32) - also called Gen Yers -- are facing a new bare bones economy where industry expertise is expected but job training is in short supply. While $83 \%$ indicated that choice played at least some role in adopting the independent work path, Gen $Y$ is less likely to have chosen independent work completely (40\% vs. $61 \%$ of others). Gen Yers want to do what they love and they value flexibility, but they also face high levels of unemployment. Twenty-five percent listed an inability to find permanent work as a reason for going independent. Nearly a third - 29\% - turned to independence as their first job after school. (MBO, 2012, p. 8)

Regardless of whether it is a choice or not, it appears inevitable that a continued shift to nonstandard forms of employment occur in the future, and, for better or worse, the rise of coworking cannot be de-coupled from this trend. So what are the implications of precarious employment on employment spaces? Increasingly, contract and temporary workers are excluded from 'the office' in the traditional sense. Left to their own devices, these workers must provide their own work environment - whether it is working from home, working from a coffee shop, or, the focus of the paper, working in a non-traditional shared office space. As a result, this decentralization of work has implications for workers, but also on city systems that are designed to support traditional work patterns.

\footnotetext{
${ }^{1}$ Adult Millenials were born in the period between 1982 \& 1993.
} 


\section{Planning for Contemporary Employment}

"A successful city is one with a competitive advantage over others locally, nationally and internationally. It has a quality of life that will attract and retain people who have capital, skills, knowledge, ingenuity and creativity." - City of Toronto Official Plan (Wright, 2010, p. 1-3)

The preceding discussion illustrates the rise of three movements happening parallel to the rise of coworking spaces that enable and support the growth of the phenomenon, specifically the knowledge economy, the increase in collaborative consumption in the context of the sharing economy, and a rise in non-standard employment conditions. As coworking is generally considered to be a phenomenon of large, urban city centres, it should be analyzed in the context of larger trends governing cities, and correspondingly, with the actors shaping those cities. This is where the importance of planners emerges in relation to coworking sites.

Planners, both directly and indirectly, shape cities. The responsibilities of urban planners are broad and varied, but for the most part, cover a range from a regulatory or administrative role to a visionary role. They are engaged in imagining the future city and the tools, structures, and processes needed to achieve that vision. Many branches of planning impact everyday city life. For example, social planners support the development of socially cohesive cities, while transportation planners support the development of effective transport networks to support competitive and accessible city regions. The objects of planning - land use, transportation, social systems, impact a city's liveability, which in turn impacts the attractiveness of the city both as a place to live, and a place to work.

In a more direct sense, land use planning impacts employment patterns throughout the City by regulating the areas that support various categories of employment through tools such as the zoning by-law and secondary plans. These documents are the local tools of implementation for broader regional and provincial policies in Ontario, with powers defined under the 1990 Planning Act (refer to Figure 3). 
Provincial Policy \& Legislation

- Ontario Planning Act

- Provincial Policy Statement, 2014

- Growth Plan for the Greater Golden Horseshoe

\section{Municipal Policy}

- Official Plans

- Supporting Policy Documents

\section{Municipal Tools of Implementation}

- Zoning By-laws

- Secondary Plans

- Site Plan Control

Figure 3 - Hierarchy of Planning Tools \& Policies

These documents set out visions and policies that inform local documents, and are enshrined through municipal planning tools. A sampling of statements from these various high-level documents (refer to Table 1) illustrates how planning policy addresses employment ${ }^{2}$. Table 1 - Planning Policies Impacting Employment

Planning authorities shall promote economic development and competitiveness by:

a) providing for an appropriate mix and range of employment and institutional uses to meet long-term needs;

b) providing opportunities for a diversified economic base, including maintaining a range and choice of suitable sites for employment uses which support a wide range of economic activities and ancillary uses, and take into account the needs of existing and future businesses;

c) encouraging compact, mixed-use development that incorporates compatible employment uses to support liveable and resilient communities; and

d) ensuring the necessary infrastructure is provided to support current and projected needs.

\footnotetext{
${ }^{2}$ This is in no way a detailed policy scan. Instead, key policies are highlighted for their relevance, and to illustrate the efforts of planners aimed at impacting employment in cities.
} 
a) promoting opportunities for economic development and community investmentreadiness

b) optimizing the long-term availability and use of land, resources, infrastructure, electricity generation facilities and transmission and distribution systems, and public service facilities;

c) maintaining and, where possible, enhancing the vitality and viability of downtowns and mainstreets;

d) encouraging a sense of place, by promoting well-designed built form and cultural planning, and by conserving features that help define character, including built heritage resources and cultural heritage landscapes;

e) promoting the redevelopment of brownfield sites;

f) providing for an efficient, cost-effective, reliable multimodal transportation system that is integrated with adjacent systems and those of other jurisdictions, and is appropriate to address projected needs to support the movement of goods and people; ...

\section{Growth Plan for the Greater Golden Horseshoe}

\begin{tabular}{|c|c|c|}
\hline \multirow{3}{*}{$\begin{array}{l}\text { Section 1: } \\
\text { Unique } \\
\text { Features } \\
\text { of the } \\
\text { GGH }\end{array}$} & $\begin{array}{l}\text { "An economy in transition, with economic activity and wealth increasingly } \\
\text { generated by service and knowledge industries" }\end{array}$ & p. 7 \\
\hline & $\begin{array}{l}\text { "A highly educated workforce, whose social and economic diversity are } \\
\text { critical factors for success in the growing knowledge economy" }\end{array}$ & p. 7 \\
\hline & $\begin{array}{l}\text { "Cultural amenities that offer the kinds of creative and recreational } \\
\text { activities that attract knowledge workers" }\end{array}$ & p. 7 \\
\hline \multirow{2}{*}{$\begin{array}{l}\text { Section 2: } \\
\text { Where \& } \\
\text { How to } \\
\text { Grow }\end{array}$} & $\begin{array}{l}\text { Providing opportunities for businesses to locate in the GGH is } \\
\text { fundamental to using land wisely and ensuring a prosperous economic } \\
\text { future. }\end{array}$ & p. 13 \\
\hline & $\begin{array}{l}\text { Population and employment growth will be accommodated by - } \\
\ldots \text { f) ensuring the availability of sufficient land for employment to } \\
\text { accommodate forecasted growth to support the GGH's economic } \\
\text { competitiveness }\end{array}$ & p. 14 \\
\hline $\begin{array}{l}\text { Section 2: } \\
\text { Where \& } \\
\text { How to } \\
\text { Grow }\end{array}$ & $\begin{array}{l}\text { Municipalities will promote economic development and competitiveness } \\
\text { by - } \\
\text { a) providing for an appropriate mix of employment uses including } \\
\text { industrial, commercial and institutional uses to meet long-term needs } \\
\text { b) providing opportunities for a diversified economic base, including } \\
\text { maintaining a range and choice of suitable sites for employment uses } \\
\text { which support a wide range of economic activities and ancillary uses, and } \\
\text { take into account the needs of existing and future businesses; } \\
\text { c) planning for, protecting and preserving employment areas for current } \\
\text { and future uses } \\
\text { d) ensuring the necessary infrastructure is provided to support current and } \\
\text { forecasted employment needs. }\end{array}$ & p. 17 \\
\hline
\end{tabular}


Based on these statements, planners are actively involved in:

- Identifying the need for diverse employment opportunities;

- Tracking trends in employment;

- Recognizing the need to create city-regions that are attractive to knowledge workers;

- Emphasizing the importance of providing the necessary infrastructure to support different types and forms of employment; and

- Utilizing land use planning as a tool for the spatial distribution of employment.

Each of these activities can influence coworking - in terms of the potential distribution of spaces, the potential market for coworking, and the overall attractiveness of the city, and therefore the connection between planning and coworking, although not immediately obvious, exists and should continue to be explored. 


\section{PART II - By the Books: The Literature on Coworking}

Academic, peer-reviewed literature on coworking is limited in scope. In the following review, I highlight key pieces (both peer-reviewed and independent) in order to provide greater context and insight into previous studies of coworking.

\section{A Broader Perspective on Coworking}

Previous work has explored coworking in connection to some of the larger trends identified in Part I. For example, Moriset (2014) explores the rise of coworking spaces as they relate to two factors both the rise of the creative economy and the digitization of the economy. The tendency towards outsourcing and subcontracting that has come with these two trends has led the creative class search for 'third' places to break loneliness. Oldenburg (1989) first explored the notion of the third place as "a generic designation for a great variety of public places that host the regular, voluntary, informal, and happily anticipated gatherings of individuals beyond the realms of home and work" (p. 16). Ultimately, Moriset concludes that coworking ideals are consistent with conceptions of the third place (as illustrated in Figure 4 below). Along with this notion, consistent with Kenline (2012), there is a focus placed on the increased serendipity that occurs in these spaces.

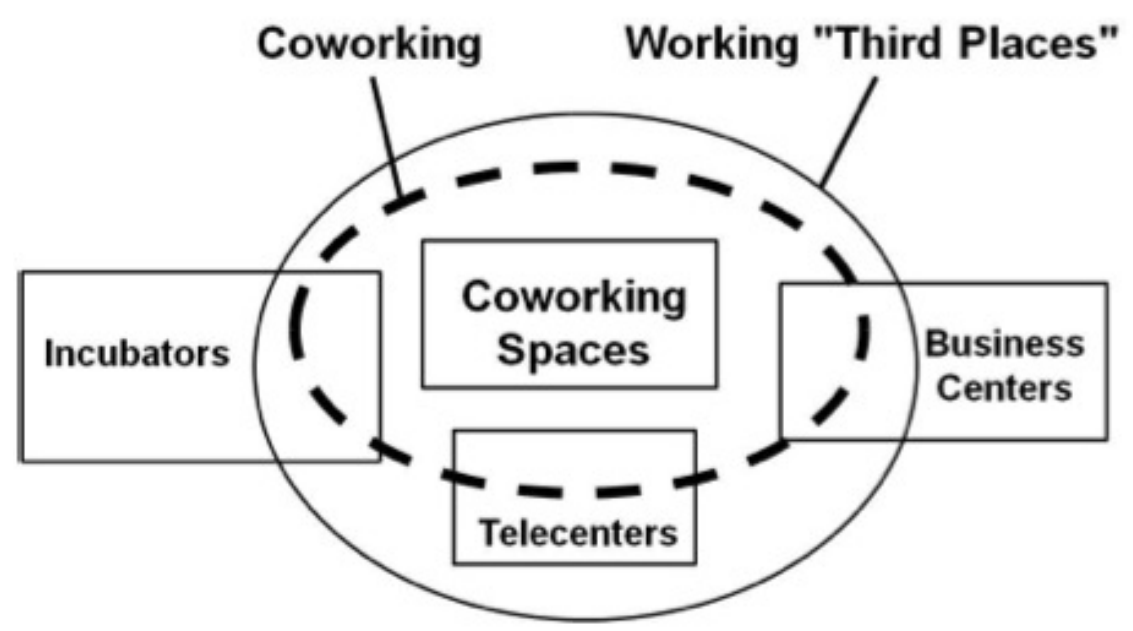

Figure 4 - Coworking spaces as "third places"; From Moriset (2014) 
In one of the few explorations of coworking in the broader context of the city, Moriset (2014) explores the distribution of coworking spaces (CS) around the globe, suggesting that coworking is primarily focused in so-called 'creative cities'. He suggests that while "hundreds of cities host CS, but a few boast a dense network of facilities" (p. 11). ${ }^{3}$ This provides some indication of a relationship between these sites and the knowledge economy, and, at the City level, of the importance of coworking sites in retaining knowledge workers. However, it remains unclear whether these sites are precursors to the success of the City or simply indicators of a thriving creative class. Moriset also explores the spatial distribution of sites within cities, suggesting that coworking spaces appear to occur in localized clusters, such as in Paris where they are all located in older industrial areas that have been revitalized (i.e. the Garment district).

Ultimately, Moriset questions the promotion of these spaces, given that they may be subject to the cycling of the economy, in terms of corresponding increases or decreases in the number of nonpermanent employment positions, tendency to outsourcing, etc. He suggests there is some evidence that the spaces are largely not profitable, and they may not be encouraging the most desirable type of work. He argues that entrepreneurs may be targeting flexibility rather than innovation through self-employment, and that start-ups may not support a robust economy "because small, newly created firms often feature low paid, short-tenured jobs, low value-added per worker, and little innovation...supporting the growth of carefully chosen existing firms would make a better return of public money" (p. 17).

These concerns are reinforced by (Land, Otto, Böhm \& Johansson, 2013), who similarly emphasize the precariousness of work for 'creatives'. They question the role of entrepreneurship in driving the economy, emphasizing that the connection between entrepreneurship and growth should not be assumed. Entrepreneurs might have downsized purposefully to achieve a better work-life balance, and are not necessarily trying to grow their business (consistent with Moriset, 2014).

\footnotetext{
${ }^{3}$ Density in this case is measured simply as the number of spaces in a particular city region, An alternate measure would be the number of coworking spaces / capita, which would perhaps indicate cities that are outliers, either in terms a relatively high number of spaces per person in a smaller city, or vice versa. Toronto is listed within the top 10 cities by number of spaces based on the list provided by Moriset.
} 
However, they do acknowledge that even 'big business' seems to be attracted by the notion of coworking:

In the Berlin cases we studied, for example, several large MNCs had relocated close by at least partly to take advantage of the opportunities to access creative and knowledge based workers in sub-contracting networks. This had impacted upon the local area, encouraging a form of regeneration that boosted property prices and risked keeping out other, similar startups that had located there initially because of the cheap rents. In some respects, then, the co-working space fits into Richard Florida's (2002; 2005) model of urban regeneration in which creatives, artists and hipsters, attracted to an area for the cheap accommodation and studio space, create a bohemian environment that in turn attracts other members of the creative class, including knowledge workers and professionals, to a city/area. (Land, Otto, Böhm \& Johansson, 2013, p. 2)

Capdevila (2013) explores a more positive conception of the coworking space, one that posits the impact of a coworking space on its tenants as similar to that of larger corporations in clusters. He refers to 'micro-clusters' - clusters that develop between individuals at the site, in contrast to the traditional notion of clusters that refers to ties between corporations or 'meso-clusters' that refer to bonds within an organization. Clusters and micro-clusters are compared in Figure 5 below.

\begin{tabular}{|c|c|c|}
\hline & CLUSTERS & COWORKING SPACES (CWS) \\
\hline Type of members & Organizations & Micro-firms, entrepreneurs, freelancers \\
\hline Level of geographic impact & Region, city & City, district \\
\hline Interaction with local citizens & Limited & Medium / High \\
\hline Public policy intervention & High / medium & Low \\
\hline Shared resources & $\begin{array}{l}\text { Infrastructures (public and private) } \\
\text { and shared services }\end{array}$ & $\begin{array}{l}\text { Office facilities and services (printers, } \\
\text { internet connection, etc.) }\end{array}$ \\
\hline $\begin{array}{l}\text { Type of relationships } \\
\text { between insiders }\end{array}$ & Collaboration and competition & Mainly collaboration \\
\hline \multicolumn{3}{|l|}{ Knowledge dynamics } \\
\hline $\begin{array}{l}\text { Interaction modes between } \\
\text { members }\end{array}$ & $\begin{array}{l}\text { Formal and informal, face-to-face and } \\
\text { virtual }\end{array}$ & Informal face-to-face \\
\hline Type of knowledge shared & Tacit and codified & Mainly tacit \\
\hline Local buzz & Knowledge shared within the cluster & Knowledge shared within the CWS \\
\hline Global pipelines & Interaction with distant similar clusters & $\begin{array}{l}\text { Interaction with other local and distant } \\
\text { CWS }\end{array}$ \\
\hline
\end{tabular}

Figure 5 - Characteristic comparison between cluster and coworking space; From Capdevila (2013) 
Similarly, Parrino (2013) explores "the role of proximity in facilitating interaction and transmission of knowledge among those working within specific shared work environments: coworking spaces" (p. 1). Ultimately, Parrino suggests that spaces that encourage and support interaction (what may be termed a 'genuine coworking space') do have the effect of facilitating knowledge transfer. In summary:

All the respondents reported knowledge flows with other coworkers, even recurrent or placed in the context of collaborative relationships. The manifestations of sociality among coworkers were found to be frequent. On the professional level, both collaborative relationships (sometimes potential) among coworkers and the role of internal bonds in creating job opportunities with external parties proved to be significant: the experience in the space helped to expand the network of collaborations and labour services of the coworkers. (p. 9)

This is distinct from knowledge flows in coworking spaces that are structured more as simply shared office spaces. In these cases "few manifestations of sociality and an absence of customersupplier or collaborative relationships were found. The experience in this space seems not to have played any role in expanding the networks of collaborations and labour services of the coworkers. The transmission of knowledge among coworkers proved to be scarce and episodic" (p. 9).

Surman (2013) also explores the potential for knowledge exchange occurring in coworking spaces, specifically in the context of social innovation. Surman suggests that in order for innovation to occur, a pyramid anchored by the physical space of the coworking office is needed (refer to Figure 6). In other words, "space is the foundation, and the platform for everything that happens" (p. 191). Surman emphasizes the design of the space itself as one of the critical elements in contributing to innovation, and one of the key

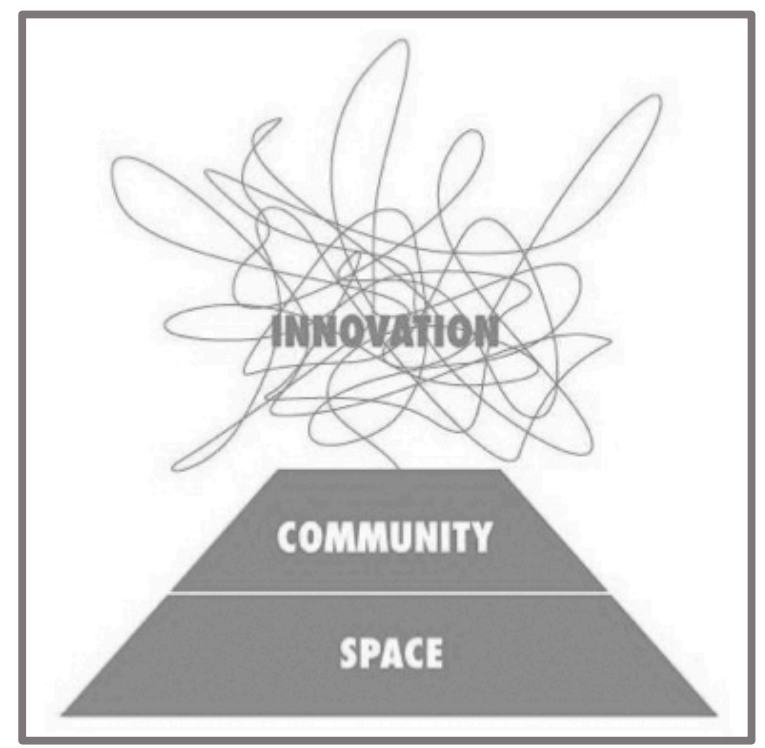
differences between a traditional space and a Figure 6-CSI Theory of Change; Surman (2013) coworking space, suggesting, "not all spaces are created equal, and some spaces are more clearly conducive to creativity and innovation than others. A space created to foster social innovation must be designed as a social space, and it must have features that encourage people to generate new ideas and connections" (p. 191). 
Overall, it is interesting to note that most broad analyses of coworking, although they include a spatial element and draw on notions of the creative city, are rooted in economic and business literature. Planning pieces that explore the social implications or the local impacts of these sites are largely missing at this scale of analysis.

\section{The Coworking Concept \& City Design}

Interestingly, there has been some work done to apply the concepts of coworking in the implementation of urban design. Forlano (2012) facilitated a program entitled Breakout! Escape from the Office, which sought to explore city design for a mobile workforce in a manner that encapsulates both the community element of coworking and the physicality of coworking - in other words, taking the work out of the office and into public spaces. The program was intended as a design intervention, "following a yearlong collaborative research process that experimented with the conditions for mobile work as well as the opportunities for interdisciplinary linkages ad collaboration in public settings" (p. 454). This is an interesting example because it illustrates a different dimension of the connection between the sharing and knowledge economy at the intersection of planning and design. A series of events were staged to facilitate coworking in outdoor settings - for example in parks and public squares, and to investigate the challenges of working outside in public settings. Ultimately the research identified a number of possible design interventions in cities, even suggesting a role for public policy in supporting the needs of mobile workers:

At present, mobile workers are forced to sustain much of the burden of interaction, motivation, and monitoring while at the same time experimenting with different types of connectivity and searching for suitable places to work... As such we may view mobile workers as a new constituency with shared experiences and needs but for which there is not yet clear leadership or an agenda. (p. 455)

While certainly a different exploration of coworking, the adoption of a coworking model to explore the adaptability of city spaces to the mobile workforce illustrates the emerging influence of coworking on explorations of urban issues.

Nonetheless, this experiment with urban design is one of the few examples of work relating coworking to urban spaces. Limited evidence of literature about coworking within planning literature as it relates to any other areas, such as policy, illustrates a void in existing work. 


\section{Coworking Around the World}

Since this project applies a case study approach in the City of Toronto, an effort was made to identify academic case studies of coworking from around the world, in order to build upon existing findings and techniques. Qualitative research was noted in several cities throughout the US and globally, with key studies discussed here.

\section{Austin, Texas}

Spinuzzi's qualitative study of coworking study in Austin (2012) represents one of the more comprehensive case studies to date. Carried out over a two-year period, it relied on a qualitative approach, examining coworking from an activity theory perspective. Researchers conducted interviews with both coworkers and owners across nine coworking spaces. In addition, written materials (business plans, Web sites, collateral, site reviews, social media) that describe those sites were reviewed using a 4GAT ( $4^{\text {th }}$ Generation Activity Theory) framework. Through these techniques, the study attempted to address three main research questions - specifically: what is coworking, who is doing it and why.

Spinuzzi (2012) emphasizes similar trends of increasingly flexible work arrangements and the advent of mobile technology, as introduced in Part I, noting that:

On one hand, more people (nationally, but especially in Austin) can work anywheretelecommuting, collaborating electronically, running their own businesses with mobile phones and laptops. On the other hand, their freedom to work anywhere often means isolation, inability to build trust and relationships with others, and sharply restricted opportunities for collaboration and networking. One emerging solution to these drawbacks is coworking. (p. 4)

His findings suggest that the notion of a unified concept of coworking may be flawed. He identifies and develops a typology of the role of a coworking space, based on owner interviews and materials. The three types of coworking spaces he identifies include:

- Community Work Spaces - The owners of these spaces "defined themselves in terms of serving local communities; the object was to work alongside, but not with, others." (p. 12). This was associated with characteristics like quiet space policies, and a broader mission related to the larger community.

- Unoffice Spaces - These spaces were described as "flexible office spaces that allow workers to interact and to meet with clients; their object was to recreate characteristics of the 
traditional office environment that independent workers may miss. In particular, they emphasized that coworkers can exchange ideas and get feedback from other coworkers" ( $p$. 14).

- Federated Work Spaces - These coworking spaces include those "that foster more active connections between coworkers, connections that could lead to working relationships between businesses-contracts or referrals—" (p. 15). Interaction is considered to be very important in these spaces, with an emphasis on formal collaboration.

In contrast, coworkers do not necessarily define their coworking sites in these categories. Instead, they seem to have their own rationales for coworking that do not necessarily abide by the notions of coworking site owners. For example, formal collaboration was very infrequently stressed as one of the rationales for coworking. Instead, coworkers identify characteristics such as 'social hub', 'space' and 'collaboration' as the key components of why they use coworking spaces. In other words, coworkers "tended to emphasize the unoffice model, in particular, the combination of space and social interaction as they performed separate projects. But beyond saying that they worked in the presence of other people, they provided definitions that were far from unanimous" (p. 20). Thus, Spinuzzi concludes that a formal definition of coworking is not applicable across all coworking sites and coworkers themselves, however most coworkers appear to conceive of coworking as most reflective of the 'unoffice space' model.

Spinuzzi also develops an initial cross-section of coworkers. Some of the key findings, based on the 17 coworkers he interviewed, include:

- 10 were small-business owners (non-consultants)

- 4 were consultants

- 12 had some element of information technology to their work

Spinuzzi found that coworkers chose to use the sites for a number of reasons. All of the study participants had tried working from home, and most had tried working in coffee shops, before turning to coworking. He identified a number of factors that influenced the decision to use coworking, contrasting the importance and manifestation of these factors across multiple sites, specifically:

- Aesthetics \& Physical Space

- Flexibility 
- Location

- Benefits from other coworkers

$\begin{array}{cl}\circ & \text { Interaction } \\ \circ & \text { Feedback } \\ \circ & \text { Trust } \\ \circ & \text { Learning } \\ \circ & \text { Partnerships }\end{array}$

Ultimately, Spinuzzi develops two industry-specific models of coworking, building on the typology developed for coworking spaces. In Figure 7, a configuration of coworking more akin to the 'unoffice' form of coworking illustrates objectives of facilitating neighbourly collaboration and providing a unified professionalism. In contrast, Figure 8 shows a coworking structure more consistent with a 'federated work space', in which "unaffiliated specialists...can link up inside the coworking space...to attack shared work problems." (p. 31).

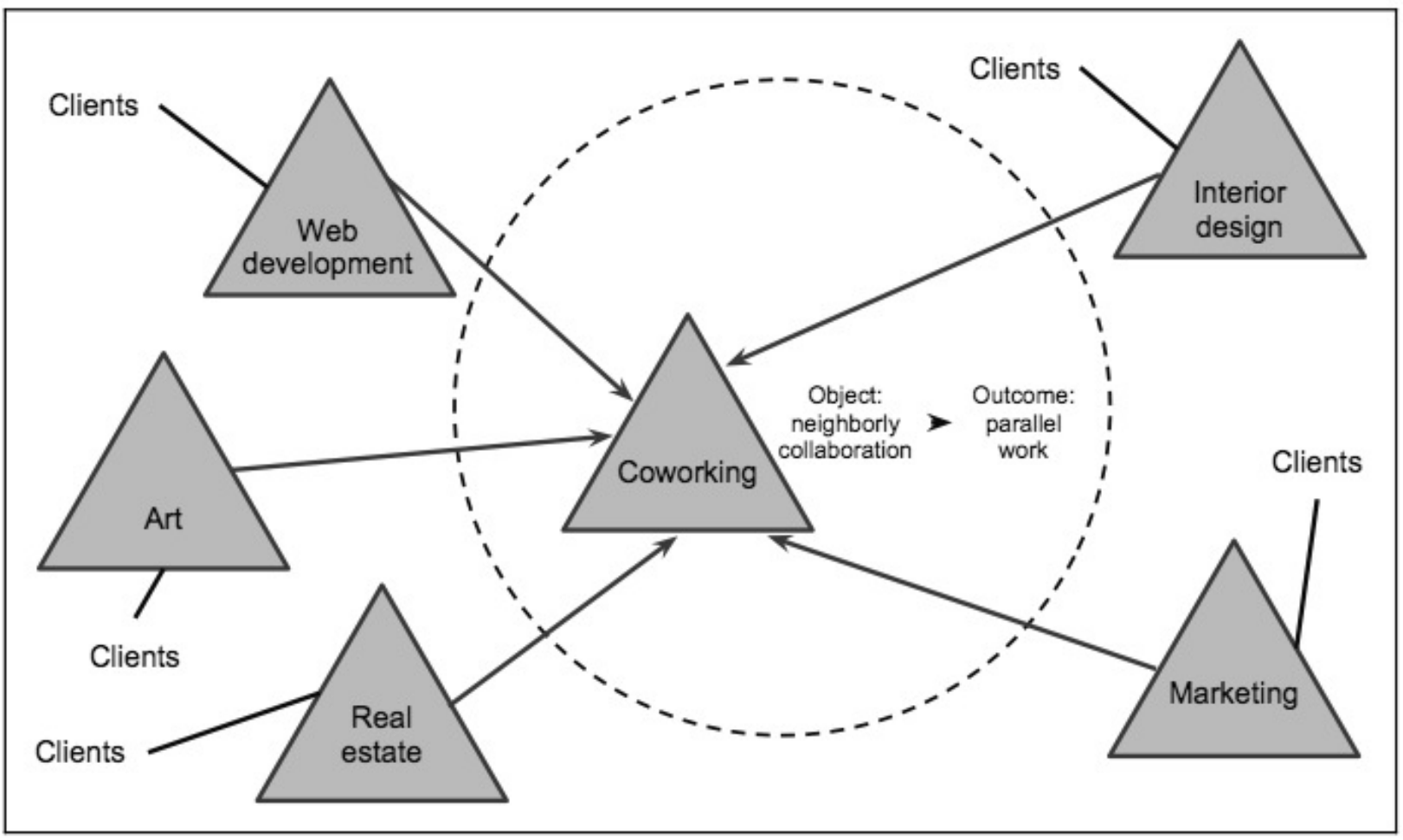

Figure 7 - The Good Neighbours Configuration of Coworking developed by Spinuzzi (2012) 


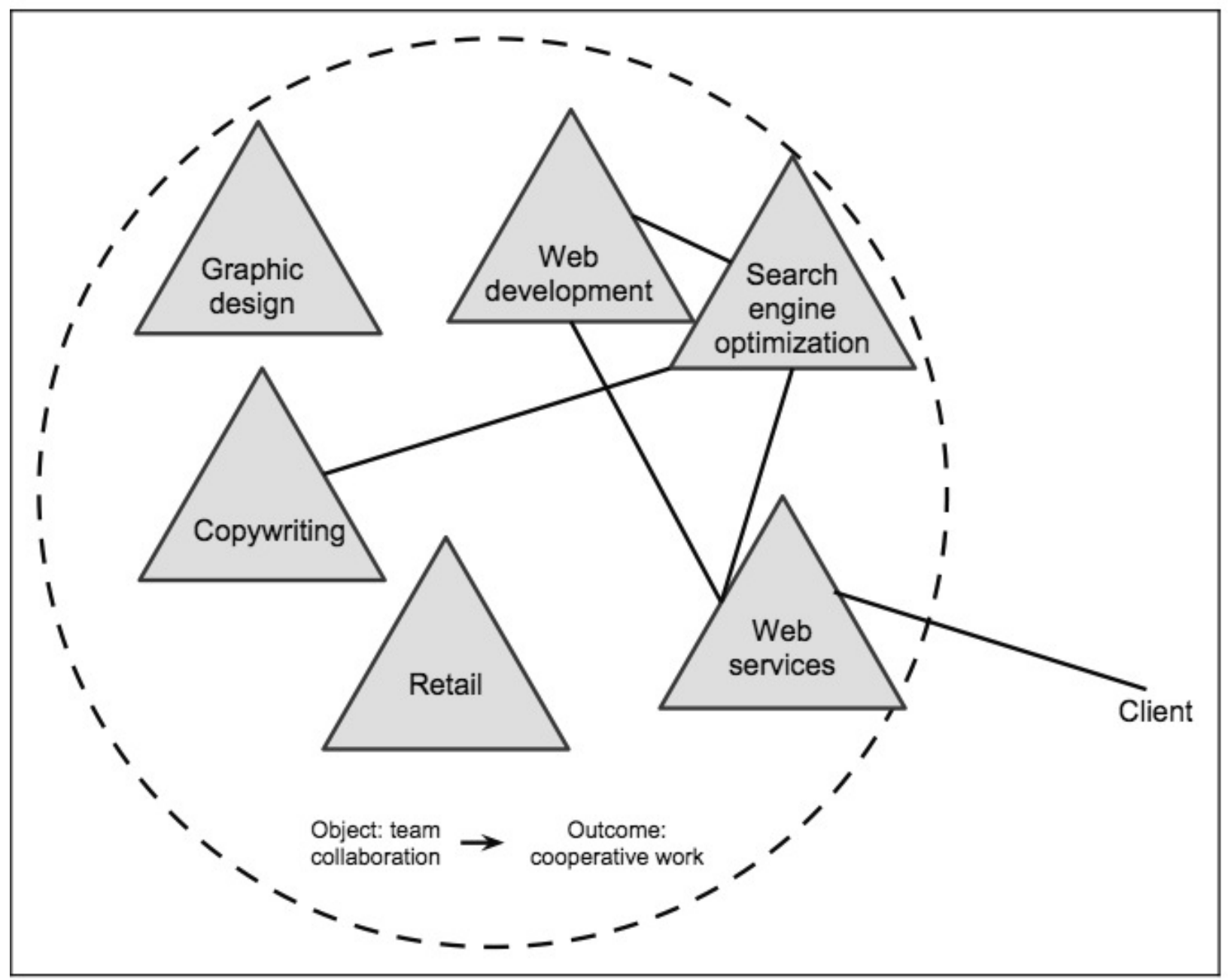

Figure 8 - The Good Partners Configuration of Coworking developed by Spinuzzi (2012)

\section{Halifax, Nova Scotia}

In the Canadian context, a qualitative analysis of coworking in Halifax was carried out by Hurry (2012). Using an exploratory approach, one-on-one interviews were carried out with two site owners and five coworkers at the Hub-Halifax, a downtown coworking site in Halifax, Nova Scotia. Results of the interviews were analyzed against existing literature to document similarities and differences. Interestingly, the researcher attempted to contact a varied audience of the coworking site. Specifically, he originally intended to conduct interviews with a current user of the space, someone who has grown out of the space and left, someone with a negative experience, and someone with a positive experience at the site. The cross-section approach would allow for a more complete picture of the impact of coworking. Unfortunately, however, the final list of five participants included four active participants (one who was described as having a positive experience), and one person who had left the site. 
Users of the site identified three key components of coworking, that can be related both to the findings of Spinuzzi (2012) and Kenline (2012):

- Shared office space \& resources - Respondents emphasized the ability to access shared resources including boardrooms, internet access, and kitchen/washroom facilities as important to their overall experience.

- Networking site - The site fostered important connections, including weak ties to support networks. For example, a respondent "spoke of the high level of interconnectedness that existed between members in her description of what coworking was" (p. 41).

- More than coworking - The space offered many workshops and activities that move the space more into the realm of 'incubator' than coworking space, since emphasis was placed on encouraging and enabling the growth of member businesses. Of course, suggesting that this category is called 'more than coworking' implies that these activities occur outside the normal definition of coworking - however some of the models identified by Spinuzzi (2012) would suggest that these activities do occur in the context of 'coworking'.

The study also explored the coworking business model, concluding that the Hub is not yet a profitable business model. The business had difficulty accessing traditional financing due to the emerging nature of the business, and this led to the development of some unique employment arrangements. For example, a barter system is used for 'Hosting' - members can access the coworking facilities for free in exchange for completing a shift at the Hub where they greet members, provide tours, and otherwise ensure the space runs smoothly. With this example, further integration of the sharing economy with the coworking model emerges.

Users of the site also noted that they were able to leverage contacts and business development through connections at the site. Specifically, one coworker was able to access business financing through another member of the site - with the connection made by the operators. This formalized collaboration can be related to the 'federated work space' conception of coworking described by Spinuzzi (2012).

Overall, the study highlighted many key benefits to coworkers using the space, including the ability to 'bootstrap' i.e. leverage alternate financing strategies and/or reduce capital expenditures to 
improve business operations. The rise of the sharing economy can be related to bootstrapping as the author notes of the barter system, "their willingness to engage in the barter system for Hub services is a synergistic bootstrapping method using the social capital of both the users and the owners to further the goals of both parties" (Hurry, 2012, p. 47).

\section{Phnom Penh, Cambodia}

Pearce-Neudorf (2014) examined three co-working spaces in Phnom Penh, Cambodia, with the primary objective of determining the extent of shared community experienced by the users and owners of these sites. This case study is notable both for taking place in the context of a developing country, but also because of the dynamic of two distinct cultural groups making use of the sites (ex-patriots and Cambodians).

Through ethnographic studies of the sites and an analysis of their role as part of a network structure, the research drew on qualitative interviews as the primary tool to achieve the analysis. In addition, spatial analysis was employed as a tool for further studying the sites. Through mapping, hubs were established representing closely situated coworking facilities and supporting additional sites identified by interviewees as places of "collaboration, entrepreneurship and innovation" ( $p$. 28).

Ultimately, Pearce-Neudorf concluded that there is to some extent a shared community of innovation and entrepreneurship throughout Phnom Penh that is connected to each of the three spaces. However, the community may not necessarily be driven entirely by the sites, since there are distinct differences in terms of the awareness of the community between each individual site, and, "given the shared goals of collaborative learning and knowledge exchange and the advancement of entrepreneurial ideals, there would seem to be much ground to develop further partnerships and the idea of an explicit community" (p. 49).

\section{Indianapolis, Indiana}

Kenline (2012) analyzed coworking as an ecosystem illustrating the sharing culture of the collaborative economy at a coworking space in Indianapolis. She explored the motivation for coworking as it relates to social capital, suggesting that "users of coworking spaces can be analyzed as using the social capital gained through coworking to have access to social networks and shared resources in order to positively impact the end products for their projects or companies" (p. 8). However, since social capital theory places emphasis on the end product, and 
coworking can more appropriately be described as a process rather than an outcome, sociocultural theory was instead selected as a basis for understanding and analyzing coworking.

Three primary research questions were explored in the work:

- What are the types of the shared resources and how does coworking provide access to these resources?

- What are the forms of social networks and the benefits of increased social networks?

- How are the complex social network and resources shared between people central to the coworking culture?

Consistent with other studies, Kenline used an observatory and interview-based methodology (Spinuzzi, 2012; Pearce-Neudorf, 2014; Hurry, 2012). Two key themes emerged from the qualitative research:

- Proximity - Proximity emerged as a key driver of coworking since it allows for resource sharing and also, by the physical layout of the space, increases the density of contact, which in turn increases face-to-face collaboration. The people in the space are considered to be the most important resources, more critical than say, photocopiers or boardrooms.

- Strong \& Weak Ties - Coworking contributes to the development of both strong and weak ties, which enable serendipitous interactions leading to innovation and improved networks

\section{A New Lens}

While these studies have examined the phenomenon of coworking and the experiences and motivations of those undertaking this activity, there has been little consideration of how coworking may impact the physical and social city on a larger scale. This study examines coworking in order to inform perspectives of urban planners and public policy makers to begin to address an existing gap in research. 


\section{PART III - The Toronto Experience: A Qualitative Study}

\section{Scope \& Methodology}

This research lays the basic groundwork for future studies of coworking sites from an urban planning and public policy perspective. The research is premised on the belief that, as planners, being connected to the pulse of the city and documenting emerging trends is a critical component of our work.

With this mindset, the following research questions drove the development of this study:

- What are the experiences of coworkers in the City of Toronto?

- What are the potential implications of coworking sites on larger city systems, in terms of both physical and social infrastructure?

- What is the relationship between the coworking site, the coworking community and the surrounding neighbourhood?

- What role (if any) emerges for public policy in the development and operation of coworking sites?

The geographic scope for the project is the City of Toronto, located in Ontario, Canada. With a growing reputation as an entrepreneurial centre and the largest number of coworking sites of any city in Canada, ${ }^{4}$ Toronto makes an ideal case study. It is home to Coworking Toronto, an online collective of 'genuine' coworking sites in the City, and it is also the administrative centre for both Coworking Ontario and Coworking Canada (personal communication, 2015). Even globally, Toronto is identified in the top ten cities in the world by

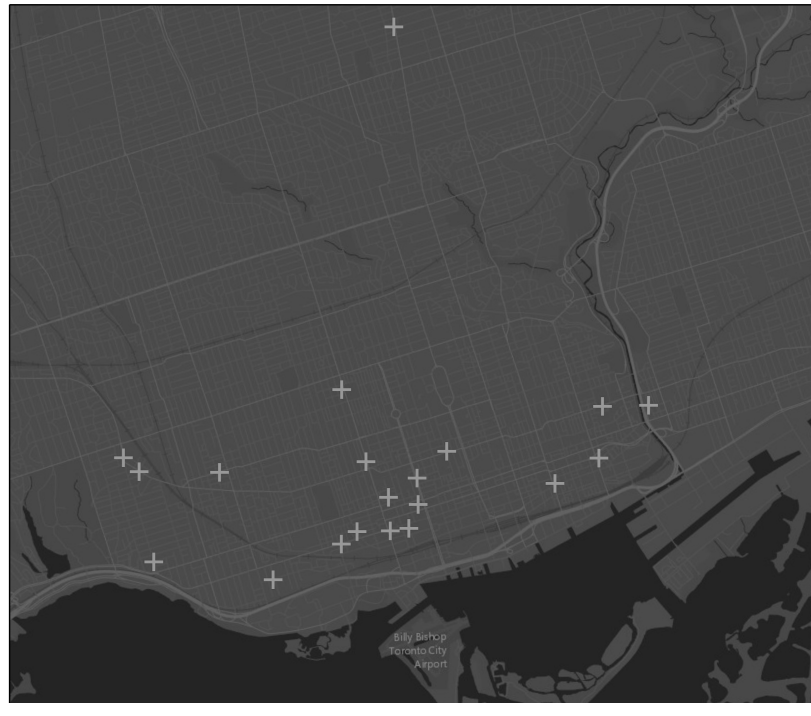

Figure 9 - Coworking Spaces in the City of Toronto

\footnotetext{
4 Based on the directory of genuine coworking spaces provided by Coworking Canada, available here: http://www.coworkingcanada.ca/spaces/. While no definition is provided of 'genuine' spaces, based on discussions with coworkers, these would include spaces that actively emphasize the community aspect of the shared space.
} 
the number of coworking spaces (Moriset, 2014). Coworking spaces across the City of Toronto (as of early 2015) are illustrated in Figure 9.

The project obtained ethics approval from the Ryerson University Ethics Board. Initial recruitment was carried out via emails sent to coworking sites that appeared to be active based on their online presence. An initial list of coworking sites was obtained from a national coworking database (coworkingcanada.com). The owners of the sites were provided with information about the study, including a recruitment poster, with the hopes that the information would be passed along to coworking members (through listserv or similar). By asking coworking owner / operators to pass along information about the study to members, snowball recruiting was initiated. In snowballing, "the crucial feature is that each person or unit is connected with another through a direct or indirect linkage" (Neuman, 2006, p. 222). When conducting interviews with coworkers, several suggested other potential participants for the study. Every effort was made to ensure the privacy of participants, including the assigning of participant codes, and the use of private boardrooms for conducting interviews whenever possible.

The study was conducted using qualitative techniques. Over a period of one month (February 2015), face-to-face interviews were carried out with ten coworkers and three coworking site owners. According to Neuman (2006), in face-to-face interviews "interviewers also can observe the surroundings and can use nonverbal communication" (p. 301). This is important for a study that explores that experience of the coworker, since it involved travelling to the workspace itself and interviewing the coworker 'in context'. Interviews were semi-structured, with a pre-determined list of questions that was approved by the Ryerson Ethics Board. Interviews lasted about 10 minutes - 45 minutes, depending on the interviewee, and were digitally recorded to allow for further analysis. This approach is consistent with Spinuzzi (2012) who suggested that "given the research questions, I focused not on how people acted out coworking daily but rather on how they described the object of coworking, their characteristics as workers, and their motivations for coworking" (p. 8). Other case studies have consistently used this approach to document the perceptions and experiences of coworkers (Pearce-Neudorf, 2014; Hurry 2012, etc.). It is also appropriate in the context of this study, since "exploratory researchers frequently use qualitative techniques for gathering data and they are less wedded to a specific theory or research question" (Neuman, 2006, p. 34). 
Based on the interview questions developed, the recorded interviews were carefully reviewed and transcribed for consistent themes and messaging. Excerpts were extracted within these thematic areas, and compiled to provide a perspective built on both overlapping and conflicting opinions. Quotations provided in this paper are anonymous - every effort was made to exclude any identifying information.

\section{Limitations}

It is important to note the limitations associated with this recruitment process. Since participants largely volunteered or were encouraged to volunteer by colleagues, they are a less representative sample than if they had been randomly selected. Most of the study participants were very enthusiastic about, and supportive of, the coworking industry. In other words, participants were largely those with a vested interest in explaining and illustrating the benefits of coworking. This should be considered as the results of the study are reviewed.

This is not intended to be a rigorous evaluative project. Instead, it is exploratory in nature, laying the groundwork for future research. As Neuman (2006) suggests of exploratory research "the researcher's goal is to formulate more precise questions that future research can answer" (p. 33). Within the constraints of a limited timeline, this project attempts to both explore the nature of coworking in the City of Toronto and to paint coworking in the larger light of the city.

\section{Participant Profiles}

A summary of the coworker participants included in this study is provided below in Table 2. The industries of the coworkers varied, with the group representing a diverse cross-section of careers. Many of the coworkers were self-employed, although there were some permanent full-time employees of organizations, specifically non-profit organizations. The demographics tended to be heavily skewed to a relatively younger worker - with nine out of the ten participants under the age of 35 , which is consistent with the impression of coworking spaces as hubs of relatively likeminded workers. 
Table 2 - Coworker Participant Profile

\begin{tabular}{|c|c|c|c|c|c|c|}
\hline $\mathrm{CW}$ & Gender & Age & $\begin{array}{l}\text { Level of } \\
\text { Education }\end{array}$ & $\begin{array}{l}\text { NAICS } \\
\text { Industry }\end{array}$ & $\begin{array}{l}\text { Detailed } \\
\text { Description }\end{array}$ & $\begin{array}{l}\text { Employment } \\
\text { Status }\end{array}$ \\
\hline CW1 & Male & $25-29$ & Master's degree & 5415 & $\begin{array}{l}\text { Mobile } \\
\text { Technology }\end{array}$ & Self-Employed \\
\hline CW2 & Female & $25-29$ & Bachelor's degree & 5419 & Photography & Self-Employed \\
\hline CW3 & Female & $25-29$ & Master's degree & 5413 & $\begin{array}{l}\text { Planning / } \\
\text { Public Policy }\end{array}$ & Contract Part-Time \\
\hline CW4 & Male & $30-34$ & Bachelor's degree & 5411 & Law & Contract Full-Time \\
\hline CW5 & Male & $25-29$ & Bachelor's degree & 5415 & $\begin{array}{l}\text { Web } \\
\text { Development }\end{array}$ & Self-Employed \\
\hline CW6 & Female & $30-34$ & Bachelor's degree & 8133 & $\begin{array}{l}\text { Non-profit } \\
\text { (Education) }\end{array}$ & Permanent Full-Time \\
\hline CW7 & Male & $25-29$ & Master's degree & 8133 & $\begin{array}{l}\text { Non-profit } \\
\text { (Urban } \\
\text { Advocacy) }\end{array}$ & Permanent Full-Time \\
\hline CW8 & Male & $30-34$ & Bachelor's degree & 5416 & $\begin{array}{l}\text { Sales } \\
\text { Consultant }\end{array}$ & Self-Employed \\
\hline CW9 & Female & $20-24$ & Bachelor's degree & 8133 & $\begin{array}{l}\text { Non-profit } \\
\text { (Education) }\end{array}$ & Permanent Full-Time \\
\hline CW10 & Female & $45-49$ & College diploma & 5416 & $\begin{array}{l}\text { Executive / } \\
\text { Organizational } \\
\text { Assistance }\end{array}$ & Self-Employed \\
\hline
\end{tabular}

In addition to the coworkers, the three owners I spoke to were owner-operators of the coworking business - although they typically leased commercial space in which to operate their business. In one case, the space was co-owned by a partner of the space. They came to own coworking sites through diverse paths; some had been involved in coworking for many years, while others were relative newcomers to the coworking industry.

\section{Laying the Groundwork: Understanding the Coworking Experience}

One of the initial aims of the research is to describe and illustrate the experience of coworking to urban planners and policy makers. Specifically, how is it different from any other form of working? Why does it deserve our attention? Why do coworkers choose these spaces? To understand these 
issues, coworkers were asked about their rationale for coworking and to explain the benefits that they receive as a result of using the site.

Drawing on the literature, I have compiled themes from various case studies on the advantages of coworking, as summarized in Figure 10 below:

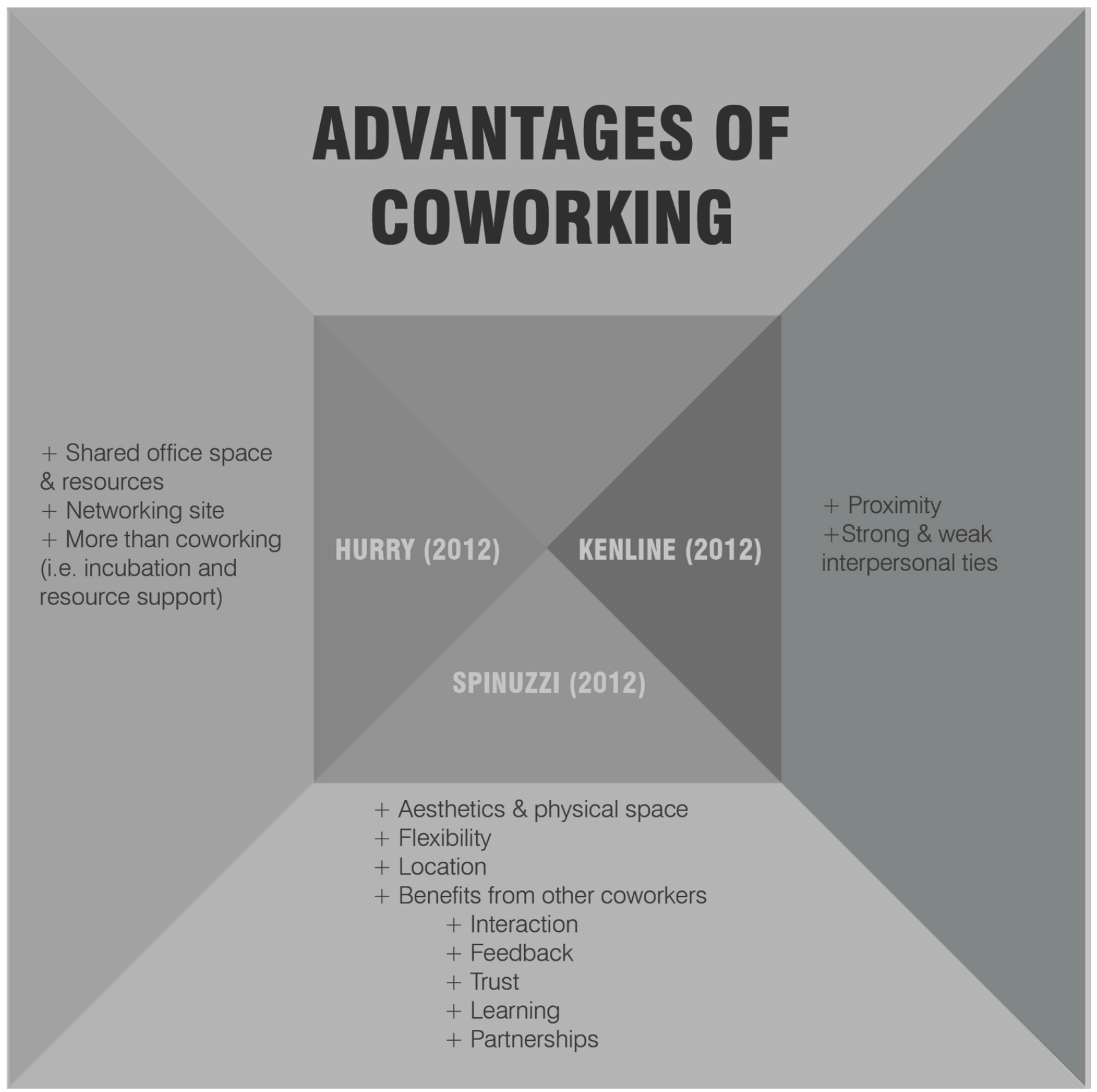

Figure 10 - Themes: Advantages of Coworking from Case Studies

Building on these themes from the literature, and reviewing transcripts, themes emerging in the context of this case study were identified. The themes can generally be grouped into two areas, personal and professional benefits, as illustrated in Figure 11. 


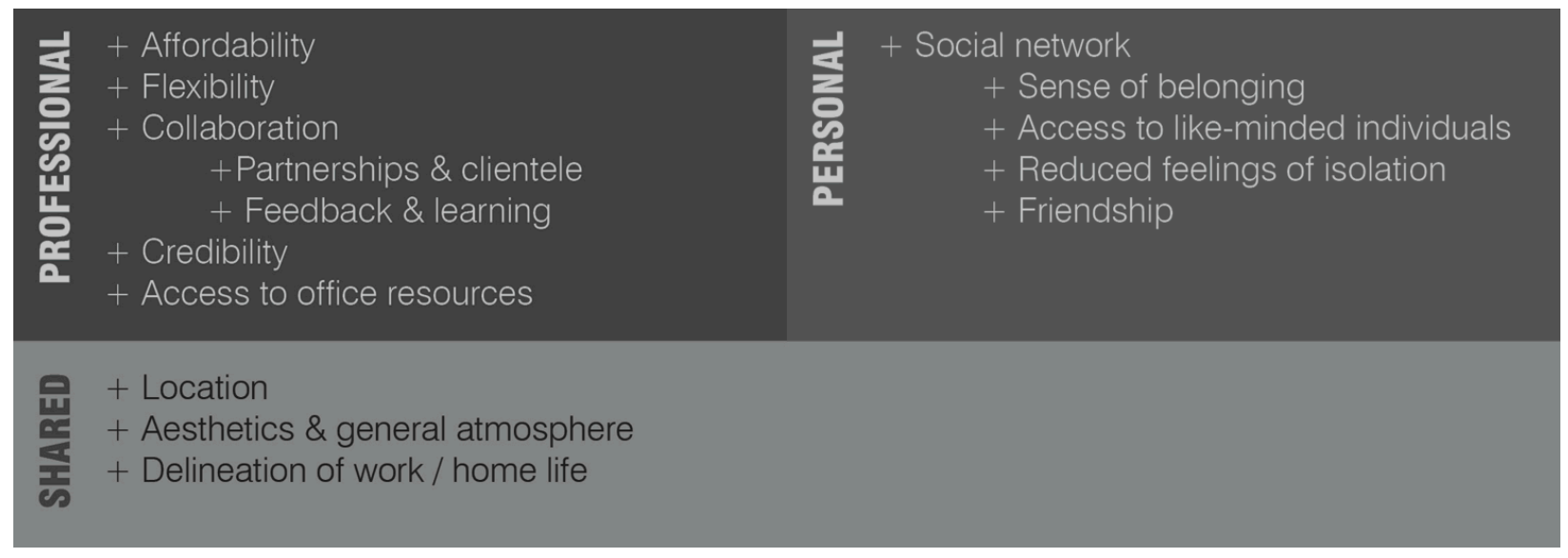

Figure 11 - Benefits of Coworking: The Toronto Experience

While recognizing that there is a significant spillover between personal and professional benefits, initial mapping of the themes was carried out to provide a structure for analysis. Benefits are broadly assigned to 'professional' if they tended to accrue directly to the business or company, while personal benefits accrue directly to the coworker themselves, and are typically less tangible, experience-related benefits. Many benefits overlap with themes identified in previous studies; however, some new benefits emerge - such as business legitimacy. While not every study participant discusses every single one of these issues, they were generally well represented in the sample. A summary of respondent responses is provided at the conclusion of this section, in Table 3. Each of these themes is explored in the following sections to illustrate how coworkers discuss these benefits. In some cases, I have grouped themes since most coworkers spoke about them in tandem.

\section{Affordability \& Flexibility}

Participants identified the price of coworking spaces (in comparison to traditional offices) as a key motivator for selecting a coworking space, in combination with the flexible leasing options. Most coworking spaces require little to no commitment and operate on a month by month basis, which allows businesses to act nimbly, adjusting as required to suit their business (and sometimes personal) needs:

...Chose a coworking space because we needed flexibility in terms of our growth whether we want to be an eight person team, a four person team, it varies on a month by month basis given the nature of our company.

Coworkers also appreciated that the spaces offered a variety of different types of memberships, which afforded the opportunity to grow, to a certain extent, within one space: 
You know I needed something affordable, and the great thing about this specific one is that they have lots of different options, in terms of, you know, the type of - the type of office you get so I get, like, the flexspace office...So this place offered me that - those options, which was number one.

People need space but it doesn't have to be so committed space. Right? And I think that's what's the good thing about coworking. You don't have to be as committed to it...there's a lot of flexibility with not just only this space but with other spaces. Yeah, it's a really good option I think for a lot of, I guess, freelance type people.

However, coworkers largely also recognize that although cost and flexibility are important, they are not the most critical factor in terms of the usefulness of the site. Most suggested that although they might not be able to afford a more expensive site, the cost savings alone was not enough to make coworking a desirable option for them on an on-going basis. Instead, coworkers placed more emphasis on costs prior to joining the coworking, and explained that as they stayed, they realized how important the community is to their overall experience:

Well, it's cheaper than a private office, so, I mean considerably cheaper, so when I was first researching offices, it was kind of a no-brainer, just for financial reasons. But now I'm staying here mostly for the community, because the community is incredible.

\section{Collaboration}

Participants spoke to the opportunities to connect with colleagues in a number of different ways. This extended the gamut from formal collaboration i.e. partnerships to bid on projects, or business transactions, all the way to brainstorming sessions or focus groups to provide feedback and opinions about ideas. While the notion of collaboration was described (and perhaps even interpreted) differently by each participant, feedback was overwhelmingly positive about the level of, and importance of, collaboration in the space:

So far my experience here has been quite positive. What l've observed and then what I've experienced have been - people conduct themselves in a singular fashion if they need to, but if they have a question, or if they want, you know, a second opinion or a third opinion or whatever, I see the interaction that goes on here and everybody is very open and willing to help or whatever...My own personal experiences or interactions with people here...I've developed at least even one client so far from here, and the interactions have been very positive.

Consistent with the work of Parrino (2013), study participants identified the presence of, and importance of, the knowledge transfer occurring throughout the site: 
In here, we'll chat all the time. We'll spend a lot of time helping each other. So there's a lot of support from others. Like yesterday, I probably spent a couple of hours with a guy, like here in this room, brainstorming things. He's like an expert salesperson, like top of the line sales guy, and he just helped me for free.

Even those who didn't experience formal collaboration appreciated the learning opportunities provided by the space:

"I mean I don't really work - I don't end up, like working with other people around me, but I have - I have found that - maybe it's less collaborative - but, you can access people resources in a different way...so in that way it's interesting... when you're in this kind of space you do have access to people with different skillsets"

Interestingly, most of the participants I spoke to worked in coworking spaces that specifically targeted a diverse client base, and they cited this as a strength of the space, allowing them to access a varied set of skill sets.

I think that it's amazingly collaborative. There's a ton of consultants - independent business people in all different types of businesses and, because it's a big collaborative, I can leverage from all of them. I've had my logo designed by somebody who does design, I have legal advice, now it's not necessarily collaborative for my business, but in general, l'm gleaning from the skill sets of the people around me.

\section{Credibility}

Coworkers emphasized the role of the space in formalizing their business operations. In other words, being in a brick and mortar location, distinct from a home office or coffee shop, improves their professional reputation and helps them navigate an increasingly competitive business landscape.

I think it just, it just frees up for me, a little bit of, it gives my business a little bit sense of more - what's the word - credibility I guess, to a certain extent. Because everything is not operating from our home and sometimes when you tell people that you operate from a home business, you know there's certain things that come into play in people's minds and they're already envisioning you know, and they're like, um, okay. But I think when you have a third party source or an outside source where you meet and greet and conduct your business, people I think take you more business-like or more serious-like.

Ultimately, there is potential for the increased image to improve business operations and success. As two participants described:

There's a bunch of like, little things that probably add up - even things like adding more legitimacy to the business, having a business address... and just being able to 
say that oh yea, I work downtown, I can come meet you guys, you know, on short notice... all of that adds some credibility - it's little but it does matter.

\section{Access to Office Resources}

Coworkers emphasized the importance of office facilities and resources as enabling them to work more effectively and efficiently, in comparison to a home office or other personal workspace. As two participants described:

But now with this, like, you have the office space and boardroom and everything so, even if I have to host something more formal, this is great. As opposed to somebody coming to my home, cause I don't have anything that's really distinguished this is my home office and this is my home, so this allows me that.

There's a lot of things you don't want to do that leads you to coworking. So I don't want to increase my internet at home. I don't want to, you know, pay - buy a printer and a scanner and a shredder and whatever you need, so the services are, it like leads you here out of convenience.

\section{Social Network}

The built in social network was almost universally acknowledged as being one of they benefits to coworkers. In some cases, the social element became increasingly more appreciated by members after joining the space:

I didn't really know this until I got here, but this is a very social place as well, and that's really something I was looking for, so, you know, from what l've - I've spoken to some other people and they say that, you know, at their place that they each had their own individual offices, people don't really interact very much, and that would have in a way just been like the same thing for me as going to a café so - you know, we all have lunch together, these have become like my friends.

In addition, the importance of the social network bleeds together with professional networking in many cases, illustrating how the personal and professional benefits overlap:

So, psychologically, I think it makes a really big difference - being able to not feel isolated, and because you're in the space where there are lots of different people doing, like all kinds of different work, but sometimes there's a lot of crossover...you'll sit down for lunch, at like, salad club and sit beside someone and you chat for a few minutes and then you realize you wanna work together on something.

\section{Location \& Aesthetics}

Most (although not all) coworkers indicated that they appreciated the physical space in which they operate. For smaller organizations, the space allowed them to leverage the same amount of 
money to access a much nicer, and often larger, space. There were also comments about the actual building layout and design, not only in terms of personal preference, but also from a business perspective:

It's also, you know, in terms of my business and the sort of brand that I wanna put forward, I feel like this physical space, like the atmosphere of this building, is kind of what I'm about, so when clients come, you know, they get that and that was important to me as well.

Location was also very important to coworkers - they tended to emphasize a desire to work close to home, so most coworkers who had control over selecting the space (i.e. the self-employed segment of the sample) chose spaces close to their neighbourhoods:

I'm very biased in that I, as the founder of the company, got to choose the location of the coworking space. So, I live about seven blocks away from here.

\section{Delineation of Work / Home Lives}

Coworkers who had tried working from home emphasized the importance of the space in separating work and home. As one participant put it:

It's prevented me from - and this is a good thing - I used to work, you know at like 11 PM at home...the fact that l've separated home and work I can come here during normal daylight hours, get my work done, and then actually live like a normal person at night which has been great, as well.

\section{Takeaways - The Experience of Coworking}

The overall message regarding the benefits of the coworking space was that it was a combination of factors at play that produced the overall positive experience. For example, none of the coworkers suggested that only price, or only facilities, were the key factors in their decisions to continue to use coworking spaces. Community was a commonality running through all of the interviews - whether the emphasis was on the business network or the social network depended on the interviewee, and I suspect is related to the type of work they undertake. Regardless, the interviewees appear to support the assertions of the larger coworking community - the spaces were seen as social and business hubs that supported 'accelerated serendipity' and provided a third space in which people came together to achieve outcomes beyond their personal capabilities. Table 3, presented below illustrates the relative frequency with which each of the elements was identified during the interviews. 
Table 3 - Relative Frequency of Various Themes

\begin{tabular}{|c|c|c|c|c|c|c|c|c|c|c|}
\hline Factor & CW1 & CW2 & CW3 & CW4 & CW5 & CW6 & CW7 & CW8 & CW9 & CW10 \\
\hline $\begin{array}{l}\text { Affordability \& } \\
\text { Flexibility }\end{array}$ & + & + & & & + & + & & + & & + \\
\hline Collaboration & + & + & + & + & + & + & + & + & + & + \\
\hline $\begin{array}{l}\text { Partnerships \& } \\
\text { clientele }\end{array}$ & & + & & + & & + & & + & & + \\
\hline $\begin{array}{l}\text { Feedback \& } \\
\text { learning }\end{array}$ & + & & + & & + & & + & & + & \\
\hline Credibility & & + & & & + & & & & & + \\
\hline $\begin{array}{l}\text { Access to office } \\
\text { resources }\end{array}$ & & & & & & & + & & + & + \\
\hline Social network & + & + & + & + & + & + & + & & + & \\
\hline $\begin{array}{l}\text { Location \& } \\
\text { aesthetics }\end{array}$ & + & + & + & & & + & + & + & + & \\
\hline $\begin{array}{l}\text { Work/Home life } \\
\text { separation }\end{array}$ & & + & + & & & & & + & & + \\
\hline
\end{tabular}

It is important to note that since the interview was only semi-structured, participants were not prompted to specifically address whether each of these issues was perceived to be a benefit to them. Instead, respondents generated their own description of why the chose to coworking, and why it worked for them. As a result, even though a specific factor may not have been identified in the interview, it does not necessarily mean that the participants don't perceive that benefit instead, it is simply not one of the factors they freely identified when describing their coworking experience.

Drawing on the typology of coworking spaces developed by Spinuzzi (2012), most coworkers described themselves operating in sites with similar experiences to either 'Unoffice Spaces' or "Federated Work Spaces". For example, one coworker described his coworking site as a selfsufficient entity that benefits everyone:

For a one man show, I have skills sets at my disposal whether on a barter type, you know, exchange - like with my logo he made it for me for free and asked whenever there's an opportunity to offer his services that I do and I have, and I hope it works out to be already evened up; or legal advice or finance advice, I mean it's all available to me. We have a fully functioning multi skill-set company here, we're just all individuals and, and not really connected other than through the cowork space. 
This closely resembles the conceptualization of coworking space as a 'federated work space', which operates as a self-dependent unit, with access to multi-skill sets within an internal community.

However, a greater number of coworkers described a site that is more consistent with unoffice spaces, reflecting a lower level of formal collaboration, and placing the emphasis on recreating the services, atmosphere, and social network available through a traditional office. As participants suggest:

A lot of connections that I'm making - that is probably by far the biggest value is the other people that I'm meeting. When you work either alone or in a very small team, you really need to put effort to meet other people because you don't naturally meet other people if you work in a very small team... So basically, I have as many connections as people would have in the typical workplace except here I think the kind of connections you have are different - I would argue they're better because they're more entrepreneurial and they're from all different kinds of industries.

There's sort of two reasons. One is just productivity. So, for the first year and a half, I was working from home, and you know, distractions, there's television, there's sleeping at random hours of the day, there's, you know all that kind of stuff. I would go out to cafes and whatnot but there's only so long you can actually sit, you know. So I found that I wasn't accomplishing what I would like to accomplish. And the second reason, and almost - this is probably the bigger reason - was because I just got sick of being by myself all day, pretty much. You know when you work for yourself and your self-employed and you work from home and you live alone, there's not a lot of social interaction, so I was looking for something like that for sure.

Clearly then, the coworking model may be perceived differently by different members. Overall, however, the participants largely identified themes and messages consistent with the benefits typically promoted by the coworking community.

\section{Establishing a Scope for Coworking}

In order to consider the potential impacts or role of coworking in the context of the City, it is important to consider the magnitude of the coworking trend. In other words, how big can it be? While the population segment involved may not necessarily define the potential reach of the trend in terms of impact on economic development impact, it can provide an initial proxy. So how do owners and coworkers envision the potential of coworking? 
While there was no consensus amongst interviewees about the numerical potential for coworking to occur as a percentage of the total workforce, owners were largely optimistic about future growth in the industry. Some owners were extremely confident about the potential:

I think anything is possible. I really think that maybe $75 \%$ or more of people could use a coworking space. We hear a lot of people who say 'I can't work in that environment', but we even recommend to them that they get a part time pass or something and they come in one day a week and they just do their accounting on site with everybody else if they have to be in another type of environment the rest of the week, so I think there are coworking options for everybody

Without assigning a specific number, most owners clearly made the connection between a decentralizing work model and a corresponding rise in coworking.

Well I think for a growing percentage of the population it's going to be a feasible work form. I think as our economy - and I think if you look to Europe, which you could either say are ahead of us economically or behind us, depending on, you know, how you want to sort of think about it - but as their economy, you know, has fundamentally sort of gone through a massive upheaval, you've seen the corresponding rise in coworking spaces. As primarily younger people, but not exclusively because I think it kind of brackets both ends of the demographic, but you know as younger people are graduating and finding the challenges with finding permanent full time employment so they're either, you know, going out to work for themselves, or they're taking contract jobs, or temporary positions as the case may be. And then also I think workers, sort of like myself, who are perhaps ending a traditional career, looking for something, or they've been laid off, and either looking to be a consultant or whatever. And I think all the data shows that those numbers are increasing year over year. The number of, whether it's mobile workers, whether it's independents, whatever the case may be contract / temporary. So, I do believe coworking is definitely here to stay and I do think it's going to continue to grow and continue to be relevant.

The percentage of the population - that's a really difficult question. And I don't know what the newest or latest numbers are of the self-employed. But I would say easily half of them could be potential members, and then there's the telecommuters, and then there's those that are just starting a company but they're not really, you know, fully involved, and then there's the people that are allowed to work from home or be flexible with their work environment so I really don't know what that percentage is - but there's so many more different types of people that could work out of coworking spaces.

Clearly, coworking is seen by owners to occur along with the rise in independent work. As established in Part I, this type of work is increasing over time, with little evidence to suggest that the trend will reverse at any point in the foreseeable future. The corresponding increasing potential for the role of coworking is also established in other studies, such as Spinuzzi (2012) who argued 
that "as cities become more porous and workers become more mobile, we can expect coworking and variations to multiply" (p. 35).

Beyond simply independent workers, there is also the opportunity for reaching employees in more permanent positions who are searching for more flexible options, as alluded to by the second owner above. Coworking spaces may offer a compromise between employer and employee, and tap into a larger segment of the population, as suggested:

If they are already talking to their employers about flex time or being able to work elsewhere, then working in a coworking space is probably a better option in the eyes of the employer right now - because some employers have hesitations that if they're working from home they're not really working, or they're not really productive, or they're not really engaged or, they're you know, they're slacking off or whatnot. And really, if the work is done, then it shouldn't matter where the employee is based. But, if they're in a coworking environment, then they could still be naturally networking with all of these other people, they could be bouncing ideas off of somebody else, they could be using a small group as a focus group for one tiny portion of a project or something like that. So it's actually to the benefit of the employer to place the employee in a coworking space but perhaps let the employee choose the space, especially in a city where there's multiple - like there is here in Toronto, and have them choose the environment that works best for them as far as their productivity and their fit is concerned, but still, then the employer can still reap all the benefits of having them be there.

In order to explore the opinions of the owners, a very high-level assessment was carried out of the potential for the uptake of coworking spaces. Employment across the Toronto CMA, arranged by NAICS codes, was reviewed. Each category of employment was broadly grouped into industries with potential to work out of coworking sites compared to industries that would not. For example, the healthcare sector was largely presumed to be excluded from the coworking industry by the nature of the work - heavy duty specialized equipment and very specific operating conditions limit the opportunity for healthcare services to be provided through coworking spaces as they exist today. Manufacturing and retail operations were largely excluded as well because of the significant space and equipment requirements of these industries. On the other hand, industries that were more office-oriented or creative in nature were included, such as independent writers, law-related industries and administrative roles. In certain cases, the divisions were more subjective - for example, financial industries, particularly banking, were excluded, primarily because of the privacy and sensitivity issues surrounding the provision of these services. On the other hand, public 
administration was included, despite potential concerns about privacy that may also be important in this industry.

Although the analysis was carried out of the detailed breakdown, the higher-level compilation by NAICS sector is shown below in Table 4. Based on this rudimentary breakdown, the potential for coworking spaces could be as high as $25 \%$ of employment in the Toronto CMA. ${ }^{5}$

Table 4 - NAICS Industry Analysis: Coworking Potential

\begin{tabular}{|c|c|c|}
\hline Industry & Employment & Coworking Potential \\
\hline Accommodation and Food Services & $5.9 \%$ & - \\
\hline $\begin{array}{l}\text { Administrative and Support, Waste Management } \\
\text { and Remediation Services }\end{array}$ & $5.0 \%$ & $4.9 \%$ \\
\hline Agriculture, Forestry, Fishing and Hunting & $0.2 \%$ & - \\
\hline Arts, Entertainment and Recreation & $2.4 \%$ & $0.5 \%$ \\
\hline Construction & $6.2 \%$ & - \\
\hline Educational Services & $7.0 \%$ & - \\
\hline Finance and Insurance & $7.9 \%$ & - \\
\hline Health Care and Social Assistance & $9.6 \%$ & - \\
\hline Information and Cultural Industries & $3.1 \%$ & $2.1 \%$ \\
\hline Management of Companies and Enterprises & $0.0 \%$ & $0.0 \%$ \\
\hline Manufacturing & $10.8 \%$ & - \\
\hline Mining and Oil and Gas Extraction & $0.2 \%$ & - \\
\hline Other Services (except Public Administration) & $4.1 \%$ & $1.1 \%$ \\
\hline Professional, Scientific and Technical Services & $10.5 \%$ & $10.5 \%$ \\
\hline Public Administration & $3.6 \%$ & $3.6 \%$ \\
\hline Real Estate and Rental and Leasing & $2.4 \%$ & $2.1 \%$ \\
\hline Retail Trade & $11.4 \%$ & - \\
\hline Transportation and Warehousing & $5.6 \%$ & - \\
\hline Wholesale Trade & $3.8 \%$ & - \\
\hline Total & $100 \%$ & $24.9 \%$ \\
\hline
\end{tabular}

The limitations of this methodology are many - for example, NAICS divides employment by sector, but not necessarily by role or responsibility. There may be employees working within an industry that would largely not be conducive to coworking but within a role that is. No effort was made to address the size of employers within the various industries, which could be a key factor - for organizations beyond a certain size it likely becomes simply more efficient to operate their own space. In addition, coworking spaces could evolve over time to reflect and meet different needs,

\footnotetext{
${ }^{5}$ All percentages are shown as a portion of the total employment in the City.
} 
supporting industries that currently are difficult to place in existing sites. However, as a first analysis, it does provide a starting point for understanding the potential scope of coworking.

Of course, a more rigorous examination of the potential for growth is needed, but regardless the trend is not likely to be disappear anytime soon. Coworking deserves attention from municipalities and planners then, not just because of its recent growth, but also for its potential to continue to spread rapidly in the future. As one coworker argues:

I think that [coworking] will transform cities. Simply because - like, right now it's too insignificant - there's a couple of coworking spaces, who cares? But if everybody begins to work in that manner, then more and more, we'll have less and less of a structure of offices that sit unused...Certain industries will always keep their offices... but for everybody else, why not?

Given the potential for growth, what are the implications for the City? The next sections explore the potential physical and social implications of coworking spaces.

\section{Coworking in the City: Exploring the Impacts}

\section{Encouraging Sustainability}

Given that one of the five coworking core values is sustainability - do coworking sites help to support sustainable behaviour? While there is no academic research on the subject, there are some indications that sustainability is indeed on the radar within the coworking industry. Weeks (2013) suggests:

Coworking spaces possess a huge potential to support environmental sustainability due to their inherently sharing-oriented constitution. At its foundation, coworking supports the sharing of space, supplies and other resources, thereby cutting down on basic wastefulness. There are other steps that coworking spaces can take in order to run with the concept further, and many do so because the culture surrounding coworking is already very conducive to creative problem solving. (p. 1)

Owners emphasized the importance of the core values in running their business. For example, one owner discussed the interpretation of sustainability:

So the core values are purposely vague, and we expect people to interpret them in different ways. So for some people the sustainability is environmental sustainability, and for us that's really important as well, and was a big consideration in our renovation process. For others, the sustainability element would be more focused on being around long term, seeing this more as a movement than a trend, and so that's kind of where I'm really focused right now. 
One of the ways that environmental sustainability appeared to be emphasized was through the selection of site locations and the corresponding mode of commute used by coworkers. Nine of the ten coworkers I interviewed were largely using sustainable modes of transportation - biking, walking or taking transit. Owners were aware of the demand for an accessible location:

Every single time location is key. For us, here in the downtown core, it's affordable and accessible, TTC, it's walkable, it's bikable for, you know, 95\% our members.

And then also being close to TTC, which is a contributing factor that coworkers, the data shows generally, and my experience would bear this out, they want to be able to take public transit. A huge number of them want to be able to ride bikes, or walk. Although I do have some members who drive.

One coworker brought up the apparent disparity between the modal split of coworking spaces compared to more traditional work spaces:

I think the one thing that's really interesting is like the demographics of like, coworkers...it skews to a specific demographic. For example, the percentage of people that bike to work in this space is like, substantially higher than the percentage of people that bike to work in the rest of the public.

Of course, as the member alluded to, a complicating factor is the uncertainty about whether coworking sites encourage people to consider sustainable modes, or if the types of people who use coworking spaces are also the types of people who are interested in using sustainable transportation. More than likely, some combination of the two factors is at play.

One other potential way in which coworking sites may encourage sustainability is by introducing members to a 'collaborative lifestyle'. Botsam and Rogers (2010) speak to this concept - that it is the initial foray into sharing that sets the precedent for future behaviour.

When people enter collaborative consumption through one particular door - a clothing exchange, a car-sharing scheme, or a launderette - they become more receptive to other kinds of collective or community-based solution. Over time, these experiences create a deep shift in consumer mind-set. Consumption is no longer an asymmetrical activity of endless acquisition but a dynamic push and pull of giving and collaborating in order to get what you want. Along the way, the acts of collaboration and giving become an end in themselves (p. 217).

Ultimately, this is an area for future exploration that should consider the extent to which coworking sites consider and encourage sustainability - whether it is in building design, site selection and accessibility, on-site operations, or by encouraging more sustainable lifestyles. 


\section{Community Development}

As alluded to by Kenline (2012), perhaps the formation of social capital is one of the important contributions of coworking spaces to the City. So does the coworking space reach beyond its members? Does it impact the neighbourhood and surrounding community? Hurry (2012) found that members "saw the potential of coworking to have a positive influence on the community at large" (p. 54).

Based on the interviews with owners, albeit a small number of them, they appear to be the types of engaged business people that care about how they impact the surrounding community. In other words, they understand and emphasize their role in supporting both a network of small businesses, as well as the neighbourhoods around the space:

I think also the education and awareness would show them...the type of impact that coworking spaces can have on small business and then also within a community, because for us it's equally important to affect the members of the space as it is to affect the people who live next door and around in the neighbourhood.

For example, some of the spaces have mandates that support strong communities:

[we're] known for finding space in typically unaffordable neighbourhoods or a neighbourhood like Queen West which is quickly gentrifying and keeping that space affordable and accessible for artists and entrepreneurs to ensure that that vibrant community remains in the neighbourhood after it's been rebuilt

Owners view the space as existing in the context of the community, rather than as a completely private entity, differentiating coworking from some other forms of shared space (i.e. executive centres). As one owner suggested:

A coworking space is still a community hub, and even if - even if no one from the neighbourhood is a member of the space, the space can also be used for community events. And so, if there is nowhere else in the neighbourhood that has a large enough area for a town hall meeting, or, you know, a non-profit organization to run a program from, or something like that, then that's when a coworking space can really make a difference

There appears to be some altruistic motivation for coworking owners. For some, those motivations eclipse even a desire for profitability. Only one of the three owners I talked to indicated that the business was profitable, which is consistent with other study findings (Hurry, 2012; Moriset, 2014). 
While that could be cause for concern regarding the potential for expansion and viability of these businesses, they may not have been intended to operate profitably at all:

I wouldn't say we're profitable, that was never really the mission, but yeah, we're growing, we're expanding, we're healthy

The discussion of coworking spaces as 'third places' presented in Part I speaks to the potential role for place-making in a community. In Toronto, there is even a coworking space designed specifically as a non-profit that is actively seeking out opportunities to promote place-making, as evidenced by recent involvement in a major new development proposal. ${ }^{6}$

One of the more surprising findings from the interviews was the potential role for coworking spaces in supporting non-profit organizations. Several of the coworkers interviewed were employees of non-profits, and their experiences illustrated the importance of leveraging the coworking space for the success of the organization. As one non-profit employee put it:

Yeah, well, I mean it's been fantastic for us in a couple of regards. The first is because we are a small organization and there's only two of us in the office on a regular basis, to have just exposure to other people socially has been great - kind of to have access to a bigger, more open, more comfortable space that way versus the typical kind of office building office. That has been fantastic.

Many non-profits in the City are carrying out true city-building efforts, and their continued success is inextricably linked with community development at the neighbourhood level, but also at the municipal and regional scales. To the extent that coworking sites improve their ability to operate effectively as an organization, they deserve to be recognized for that role.

\section{Enhancing Creative Competitiveness}

There is widespread acknowledgement of the importance of attracting and retaining members of the creative class. For example, as Hospers (2003) suggests:

The knowledge economy and the related global-local paradox mean that cities, more than in the past, compete for the favours of inhabitants, companies and visitors. Every city derives benefits by attracting and retaining knowledge workers and knowledgeintensive activities. This is something from which a city can derive competitive advantage (p. 146).

\footnotetext{
${ }^{6}$ For example, a recent development proposal for a major landmark site in Toronto include a laneway which will be animated using pop-up shops, food trucks and start-ups in collaboration with the Centre for Social Innovation (CSI).
} 
Given the importance of this issue then, is there potential for these spaces to support Toronto's role in the knowledge economy by improving its attractiveness and retaining workers? Here, owners and coworkers alike provide some excellent anecdotal evidence of the ways in which coworking sites meet a specific need. For example, coworking sites could play an important role in attracting outside investment across the city. One owner described the experience of supporting the development of the new Canadian office as they grew from one employee to twenty and ultimately moved to their own facilities:

The company that came in from New Zealand - they were an educated company and they knew that as they landed on the ground in the City of Toronto that a coworking space was what they wanted because it also gave their people who were landing from New Zealand in the middle of winter a community. Right? Like, the number of people from New Zealand that I helped find condos, told them where to go to buy boots, you know, what things to think about for the winter, how long of a drive really is it to Niagara Falls - all of those types of things they benefitted from that because their company became a part of a community. And so there's a huge benefit as particularly as you're bringing people half way around the world into a city where they know no one, it's way better - and they're employee number two - it's way better to put them into a community of 65 other individuals than it is to put them in an empty office somewhere. They're going to have a better experience, they're going to be happier and therefore going to work harder and be more successful and it'll be easier for everybody. So I think, you know, for the City of Toronto to flip it on its head so that if a company's coming in and aren't asking about coworking sites - maybe they just don't know - so what if the City of Toronto or Invest Toronto, or whomever it might be is saying, you know, as you go through this transition time what about a coworking space - would that be a good option for you? I'm not convinced they are saying that.

The experience of supporting external investment is not unique to a single space:

The one neat thing that l've seen over time is that people - companies in other countries will choose a coworking space as their Canadian office, but really there's just one person in a coworking space. They are telecommuting from there - from their company in whatever other city around the world, which is pretty neat. We actually have two of them here now that are doing that - one's from France and one's from Germany. So, it's pretty neat that we have that and we've had that continuously over time, as well. There's always been at least one or two telecommuters from other countries that can work from anywhere so they work from Canada and they work from Toronto.

Coworkers also emphasized an important role of coworking spaces as representing a larger community of like-minded individuals. For example, one participant was relocating to another city, and was determined to find a coworking site there, as a way to meet people and to access a 'built- 
in social network'. Coworking sites were also related to cultures of innovation that were important to participants.

The nature of what I do I'm more interested in cities that have burgeoning start-up communities and as a direct result of that, start-up communities kind of have burgeoning coworking communities as well - so it's not coworking per se that's a cause of my desire to be in a city but it's a correlation to the other factors I'm interested in.

The potential implication of this role for coworking spaces is that if such spaces were not available to the businesses or individuals who are looking for them, they may choose a different city, or even country in which to locate. Therefore, it is a logical progression to suggest that there may be a justifiable benefit of supporting the coworking community from a municipal and regional economic development perspective. Since it is expected that attracting and retaining workers in these types of industries is critical for the future growth of Toronto, the role for coworking spaces may continue to grow in importance.

\section{Is there a Role for Planning and Public Policy in Coworking?}

There are some unique challenges for coworking owners in bringing their businesses online. As emphasized by Hurry (2012), in can be difficult to access traditional financing due to the nonstandard nature of the spaces, and their relatively limited history of financial success as a young business model. Anecdotally, obtaining insurance can also be challenging for the same reason. Spaces often require extensive renovation and in some cases zoning amendments, which are challenging for most new small business owners, and compounded, again, by the non-standard design and layouts selected for sites. The relatively limited understanding and awareness of coworking spaces, which is highlighted as one of the key challenges for the industry, compound many of these issues.

Owners largely indicated that historically, coworking has received little support or involvement from the City's economic development division. Instead, they feel as if they are really working from the ground up to build and develop the industry. As one owner says:

I still don't know if they actually even really understand what coworking is or if they understand that, you know, if you can make it easier for these independent workers to come together and collaborate - that that's a better business support and relatively affordable, right like, you know it's not all about grant money, it's not, you know, that kind of thing it's about, you know, how can we help create awareness, how can we 
make more people aware that coworking is a viable option in the City of Toronto. That alone - because we do all that heavy lifting on our own.

This opinion was shared, with another owner suggesting that:

My ideas would be more towards education and awareness in terms of government this is - so February $24^{\text {th }}$ the Mayor proclaimed Coworking Toronto Day. It's actually the first acknowledgement from city hall of coworking ever, so that's a good start, but I'm sure half of them still don't know what coworking is.

Clearly, then, there is both a perception that the City is not supportive of the coworking industry, but also, importantly, a belief that they do have a role to play. By not fulfilling that perceived role, the coworking industry feels both alienated and frustrated by a lack of acknowledgement from municipal partners.

Owners mentioned a number of potential support mechanisms. The three primary types of support that emerged from the discussions were:

1) Support from economic development in promoting coworking spaces; and coworking in general

2) Funding / financial supports; and

3) Planning support in bringing the sites online.

The most highly valued appeared to be on the promotion side, mentioned by each owner as critical to their business:

What I want is help to run the space, and help to promote the space, and help to develop coworking in general. So, I am looking for - and a number of coworking spaces are always looking for, just other ways that we can get noticed.

And so it'd be really helpful if they were aware and they understood and also, I think, if they were more aware of what we do here they would be more - not supportive financially, but just in terms of encouragement and understanding that I don't represent my small business, I represent 150 small businesses, so when I'm there in a meeting asking for something it's not for me, it's for 150 people, and that's huge in terms of economic development and impact on the City.

Funding was a more controversial topic - with some owners suggesting it, and others wary of the potential impact of government support on their business operations: 
It certainly would be great to see some of our industry specific grants or loans, as far as financial is concerned, or...something that we could, you know, apply to, say the City or some other organization to get funding for our spaces in general. There are lots of organizations that you can apply to get funding for programming - you have to completely write out the programming in advance, have everything already done and then apply for the funding - and that's great but I don't necessarily want to be running programming in that sense all the time.

I kind of steer away from government assistance in a lot of different ways... just so that we can be nimble and quick and not rely on any types of grants and funding, so I would steer away from that.

There are precedents for the funding of coworking spaces through government-based grants or programs. A 'Creative Wallonia' program in the Walloon Region of Belgium was developed specifically to fund 'innovator groups and to support the creative economy (Cagnol, 2013). Building on this program, the Walloon region has a new designation as a 'creative district' (Creative Wallonia, 2015). This new designation is intended to continue the development of the area as attractive to creative workers:

The "Wallonia European Creative District" aims at enhancing the potential of creative and cultural industries to revitalize the industrial transition of the Walloon economy. Creative and cultural industries can inspire change and develop creative synergies with traditional industries. It is about testing new visions to enhance the creative economy in Wallonia. (para. 3)

Of course, this type of funding or program is more likely to be appropriate in the context of economic development than planning departments, as the mandate for this type of funding is largely based on improving the attractiveness of the region for investment. However, there are cases where this mandate comes from an interest in supporting and retaining youth within the region, which draw more on the social underpinnings of the planning rationale.

Planning support in the development of these spaces, particularly in navigating the zoning amendment and building approval processes, was also recognized as highly valuable:

If there was somebody that, perhaps in like the city planning office that we could call upon, that could guide us through that, that we can ask these weird questions to, that would certainly be helpful. Cause as far as I know there isn't anybody that we could talk to that, you know, that knows our industry really well - and that person could also be working with any other sort of shared space. I mean, I can't imagine that the City would dedicate one person just to coworking spaces, but any other kind of collaborative workspace or shared space, so that could be the shared kitchens, the 
makerspaces, the, and even into like the executive centres and business centres and all the other, you know, sort of facets of the same sort of industry that we're in. That's a huge market - so if there was one office or one person within the city planning office that we could talk to, that intimately knows our industry, that would be a lot more helpful for us.

Renovation is difficult to go through and, you know, I think most coworking spaces it's very much a DIY. Not a lot necessarily are going to have the extra money to work with a contractor, to hire somebody to run interference with the City of Toronto for them. I suspect a lot of people are going to be either doing the work themselves or definitely acting as general contractor themselves on a renovation, so to be able to have someone within the City of Toronto who is dedicated to helping coworking spaces help meet the - yeah, the fire code and the legal requirements and all that kind of stuff, but doing it in a meaningful way. I think that would be hugely beneficial.

Clearly then, there is a desired role for planning and public policy in supporting coworking spaces. The larger question that remains, however, is whether this role should be fulfilled - and also where responsibilities would lie. For example, many of the suggestions put forward by owners are more directly linked to economic development departments than to planning (with zoning and development approval as the obvious exception). Either way, improved coordination between planning and economic development departments has been flagged as an important element to successful employment planning, so the distinction may be less important in the future (Andrew et al., 2014).

As exploratory research, it is not the purpose of this paper to dictate future policy. However, the findings presented in this report, if nothing else, make a strong case for further consideration and examination of the importance of coworking spaces in the city. Far from an afterthought, secondary to the operational challenges of running a city, the issues presented in this report are critical issues for planners and policy makers to consider. As Hospers (2003) argues,

at present, our cities are facing totally different problems, such as how to cope with maintaining their momentum on a global level in the inter-city knowledge race. In principle it ought to be possible for the authorities to come up with creative solutions in this case--even if the question of urban competitiveness is rather less tangible than the more fundamental, day-to-day problems that cities are used to wrestling with (p.154).

Accordingly, the nimble and responsive planner must always have an eye to the future - tracking and investing in the on-going vitality of cities. 


\section{PART IV - Conclusions \& Areas for Future Study}

This exploratory study examined the coworking phenomenon in the City of Toronto from the perspective of urban planning and public policy. As a result of this study, several findings emerge:

- An Understanding of the Coworking Experience - Key themes discussed by coworkers in Toronto have been mapped to provide a snapshot of the perceived benefits provided by coworking spaces in Toronto. These benefits largely corroborate claims in the popular media about the coworking experience, such as the importance of community and an emphasis on collaboration, which differentiates these sites from other types of shared spaces

- Exploration of Impacts of the Sites on the City - The study initiates a discussion about some of the potential impacts of the coworking spaces on the City in which they operate. Particularly, three directions emerge for future research and analysis regarding soft infrastructure: support for sustainability, a role in community development, and contributions to creative competitiveness from an economic development perspective. In addition, a need for detailed analysis of the impacts of these sites on hard infrastructure is identified.

- Potential Role for Planning \& Public Policy - Based on discussions with owners, potential roles are identified for municipal partners, specifically through funding, planning support and promotion / awareness.

Significantly more detailed and quantitative research is needed to clarify the role of the municipal sector, and to build a case for coworking based on thorough analysis. Building on the groundwork laid out in this study, the following key areas for future research emerge:

- Comparative Analysis of Different Types of Shared Office Spaces - Research is needed to compare the impacts of a coworking site in contrast with other types of shared spaces to confirm that these impacts are unique to this particular model. For example, executive suites are considered by the coworking community to attract a very different clientele and not to provide the same support to members from a social perspective. A comparative study could explore the benefits identified through this and previous studies to examine how they contrast with the benefits of executive centres or other rental shared spaces. 
- Exploration of the 'clustering' impacts of Coworking in Toronto - It would be useful to carry out a systematic measurement of the 'clustering' effects of coworking spaces. Do they enable knowledge transfer on a larger scale? What impacts do businesses in coworking spaces have in supporting each other and attracting new investment? This type of quantitative research could help to further support the economic development justification for public policy intervention in coworking.

- Detailed Examination of the Impacts of Coworking Sites - Research that explores the initial potential impacts of the sites in this study should be systematically explored, specifically by considering the following areas:

- The relationship between coworking and sustainability

- The role of these spaces in supporting community development

- The role that coworking spaces play in supporting the knowledge economy and attracting creative industry workers

- The different impacts and needs of coworking sites, compared to other types of employment uses, from an infrastructure perspective (i.e. transportation,

- Further Exploration of the Role for Public Policy - With the limited sample size used in this study, additional coworking owners should be interviewed to determine what public policy interventions would best support their business development, and to separate out the desired forms of support based on the specific department/responsibility (i.e. economic development, long-term planning, zoning, building approval, etc.)

In general, future research should incorporate quantitative analysis whenever appropriate, and build upon a more formalized academic definition of coworking in the Toronto context. It is recognized that these elements would provide an important contribution to documenting the trend and giving true scale to the phenomenon of coworking.

All signs point to a growing importance and role for coworking spaces in the urban landscape. Further research is needed to continue to address and examine the impacts of these sites on the surrounding city, and to map the relationship between these spaces and corresponding trends in cities. In this sense, urban planners have a special role to play in unpacking the implications of this new form of employment on city systems. 


\section{Appendix A - Survey Interview Questions}

\section{Coworking Owner Interviews}

\section{Business Motivation}

- Why did you get into the owning / operating of a coworking sites? What led you to this business?

- How long has your coworking site been in operation?

- How do you see coworking in the broader context of employment?

- For what percentage of the population do you think coworking is a viable option?

\section{Procuring the Site - Process \& Factors}

- What process did you follow to secure a site?

- What factors were critical to you in selecting the site?

- Is your space owned or leased?

- What features are critical to the use of the site i.e. what makes it work well (or not)?

- What was your site used for prior to its current use?

- Were any zoning or OP amendments required to operate your site?

- If yes, how would you describe your experience with the planning process?

\section{Developing the Site}

- How much renovation of the space was required?

- What key elements were included as part of the renovation?

- Would significant renovations be a deterrent to the selection of a particular site?

\section{Operations}

- Broadly, how successful is your site? (financially, community) What about compared to other types of sites you may have managed in the past (if any)?

- How many staff does your site employ?

- How many members do you have?

- How much do membership fluctuate (monthly, seasonally, annually)?

- Do you have any expansion plans in the near or medium future?

\section{The Experience of Coworking}

- To what extent do you feel that members draw on the pool of talent in the coworking space?

- In your opinion, what comes first - the physical coworking space or the coworking community?

- Does the development of the coworking community tend to be more organic or intentional (i.e. do you program activities in order to encourage collaboration or are members left to their own devices)? 


\section{The Planning Piece}

- If there were to be some sort of assistance to coworking or coworking sites from a public policy perspective, what would it be (specifically at the local or regional level)? (i.e. access to entrepreneurial funding opportunities, access to city programs, etc.)

- What would have been helpful to you in opening the coworking site? (i.e. fast-tracked development approval)

\section{Wrap-Up Questions}

1. What did you think I would ask you about that I didn't?

2. What is the most important thing I should know about coworking, and how it may impact the City?

\section{Coworker Interviews}

\section{Nature of Employment}

1. What sector do you work in? How long have you worked in this sector?

2. What is your title / role?

3. Are you self-employed?

4. Does your employment directly require you to be in Toronto (in other words, are you flexible in terms of the City you live in for the work you do)?

5. Would a lack of coworking sites discourage you from living in a specific city?

6. Similarly, would an availability of coworking sites attract you to a particular city?

7. Why did you choose to use a coworking site for your work?

8. How long have you been a member of this coworking site?

9. Do you supplement the use of your coworking site with other places for employment purposes (i.e. home office, coffee shops, libraries or other facilities)? If so, what are the benefits or disadvantages of the coworking site over these other options?

\section{Commuting Patterns}

1. How do you normally travel to your coworking site?

2. How long does it typically take you to travel to the site?

3. What is the maximum amount of time you would be willing to travel to reach a coworking site?

4. How frequently do you travel to the coworking site on a typical week?

5. How has the use of a coworking changed your work week, if at all? Do you work more, less or about the same hours each week? How much of that time is spent in the coworking space?

6. How has the use of a coworking changed your commute, if at all?

7. How consistent is your usage of the site throughout the year?

\section{Coworking Site - Physical \& Social Infrastructure}

1. Why did you choose this specific site? What factors influence how successfully this coworking space works for you?

2. Have you used other coworking sites in the past? 
3. If you have coworked in any other cities / countries, how would you describe any differences in experience?

4. Do you intend to remain a member of the site in the near ( $<1$ year), medium-term $(<5$ years) and/or long-term future (5-10 years)? Why or why not?

5. What is your sense of the impact of the coworking site on your business?

6. How collaborative is your experience using the site? Do you wish it were more or less collaborative?

7. What is more critical for you personally in your work - the physical space or the community of the coworking site?

8. Do you make use of any government programs related to coworking?

9. Do you use any membership services such as COHIP (a health plan for coworkers)?

\section{Demographics}

1. What is your age?

2. What is your highest level of education?

\section{Wrap-Up Questions}

3. What did you think I would ask you about that I didn't?

4. What is the most important thing I should know about coworking? 


\section{Appendix B - Detailed Breakdown of NAICS Analysis}

\begin{tabular}{|c|c|c|c|}
\hline NAICS & Industry & Total & Potential \\
\hline & All Industries & $3,121,160$ & \\
\hline $11-33$ & Goods Producing Sector & 559,510 & \\
\hline 11 & Agriculture, Forestry, Fishing and Hunting & 7,020 & \\
\hline 110 & Farming (N.E.C.) & & 冈 \\
\hline 111 & Crop Production & 3,880 & 冈 \\
\hline 112 & Animal Production & 2,210 & 凶 \\
\hline 113 & Forestry and Logging & & 冈 \\
\hline 114 & Fishing, Hunting and Trapping & & 凶 \\
\hline 115 & Support Activities for Agriculture and Forestry & & 冈 \\
\hline 21 & Mining and Oil and Gas Extraction & 6,130 & \\
\hline 22 & Utilities & 17,650 & 凶 \\
\hline 23 & Construction & 193,390 & \\
\hline 236 & Construction of Buildings & 78,960 & 凶 \\
\hline 237238 & Heavy and Civil Engineering Construction / Specialty Trade Contractors & 114,430 & $\mathbf{x}$ \\
\hline $31-33$ & Manufacturing & 335,320 & \\
\hline 311 & Food Manufacturing & 44,350 & $\mathbf{x}$ \\
\hline 312 & Beverage and Tobacco Product Manufacturing & 7,230 & 冈 \\
\hline $\begin{array}{r}313- \\
314 \\
\end{array}$ & Textile Mills and Textile Product Mills & 4,900 & 国 \\
\hline 315 & Clothing Manufacturing & 8,940 & 冈 \\
\hline 316 & Leather and Allied Product Manufacturing & & 凶 \\
\hline 321 & Wood Product Manufacturing & 4,820 & 凶 \\
\hline 322 & Paper Manufacturing & 4,250 & 冈 \\
\hline 323 & Printing and Related Support Activities & 17,900 & 国 \\
\hline 324 & Petroleum and Coal Products Manufacturing & & 冈 \\
\hline 325 & Chemical Manufacturing & 29,710 & 政 \\
\hline 326 & Plastics and Rubber Manufacturing & 18,980 & 冈 \\
\hline 327 & Non-Metallic Mineral Product Manufacturing & 7,800 & $\mathbf{x}$ \\
\hline 331 & Primary Metal Manufacturing & 6,630 & 冈 \\
\hline 332 & Fabricated Metal Product Manufacturing & 25,120 & 国 \\
\hline 333 & Machinery Manufacturing & 18,400 & 冈 \\
\hline 334 & Computer and Electronic Product Manufacturing & 17,380 & 冈 \\
\hline 335 & Electrical Equipment, Appliance and Component Manufacturing & 7,290 & 国 \\
\hline 336 & Transportation Equipment Manufacturing & 60,070 & 国 \\
\hline 337 & Furniture and Related Product Manufacturing & 20,130 & 凶 \\
\hline 339 & Miscellaneous Manufacturing & 30,550 & 冈 \\
\hline $41-91$ & Services Producing Sector & $2,561,650$ & \\
\hline
\end{tabular}




\begin{tabular}{|c|c|c|c|}
\hline 41 & Wholesale Trade & 119,280 & \\
\hline 411 & Farm Product Wholesaler-Distributors & & 凶 \\
\hline 412 & Petroleum Product Wholesaler-Distributors & & 列 \\
\hline 413 & Food, Beverage and Tobacco Wholesaler-Distributors & 17,960 & 凶 \\
\hline 414 & Personal and Household Goods Wholesaler-Distributors & 14,460 & 冈 \\
\hline 415 & Motor Vehicle and Parts Wholesaler-Distributors & 6,760 & 凶 \\
\hline 416 & Building Material and Supplies Wholesaler-Distributors & 17,840 & 冈 \\
\hline 417 & Machinery, Equipment and Supplies Wholesaler-Distributors & 35,650 & 区 \\
\hline 418 & Miscellaneous Wholesaler-Distributors & 24,580 & 曰 \\
\hline 419 & Wholesale Agents and Brokers & & 区 \\
\hline $44-45$ & Retail Trade & 354,420 & \\
\hline 441 & Motor Vehicle and Parts Dealers & 28,470 & 凶 \\
\hline 442 & Furniture and Home Furnishings Stores & 12,840 & 区 \\
\hline 443 & Electronics and Appliance Stores & 19,280 & 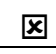 \\
\hline 444 & Building Material and Garden Equipment and Supplies Dealers & 16,850 & 区 \\
\hline 445 & Food and Beverage Stores & 87,800 & 冈 \\
\hline 446 & Health and Personal Care Stores & 28,880 & 区 \\
\hline 447 & Gasoline Stations & 6,520 & 凶 \\
\hline 448 & Clothing and Clothing Accessories Stores & 40,160 & 凶 \\
\hline 451 & Sporting Goods, Hobby, Book and Music Stores & 15,680 & 曰 \\
\hline 452 & General Merchandise Stores & 53,010 & 凶 \\
\hline 453 & Miscellaneous Store Retailers & 31,480 & 凶 \\
\hline 454 & Non-Store Retailers & 13,470 & 凶 \\
\hline $48-49$ & Transportation and Warehousing & 172,770 & \\
\hline 481 & Air Transportation & 14,280 & $\mathbf{x}$ \\
\hline 482 & Rail Transportation & & 曰 \\
\hline 483 & Water Transportation & & 凶 \\
\hline 484 & Truck Transportation & 51,470 & 曰 \\
\hline 485 & Transit and Ground Passenger Transportation & 40,210 & 凶 \\
\hline 486 & Pipeline Transportation & & 凶 \\
\hline 487 & Scenic and Sightseeing Transportation & & 凶 \\
\hline 488 & Support Activities for Transportation & 18,600 & 凶 \\
\hline 491 & Postal Service & 14,570 & 凶 \\
\hline 492 & Couriers and Messengers & 18,420 & 凶 \\
\hline 493 & Warehousing and Storage & 13,150 & 凶 \\
\hline 51 & Information and Cultural Industries & 97,650 & \\
\hline 511 & Publishing Industries & 17,070 & $\nabla$ \\
\hline 512 & Motion Picture and Sound Recording Industries & 18,560 & 区 \\
\hline 515 & Broadcasting (except Internet) & 13,720 & 曰 \\
\hline 516 & Internet Publishing and Broadcasting & & $\nabla$ \\
\hline 517 & Telecommunications & 35,780 & $\nabla$ \\
\hline
\end{tabular}




\begin{tabular}{|c|c|c|c|}
\hline 518 & $\begin{array}{l}\text { Internet Service Providers, Web Search Portals, and Data Processing } \\
\text { Services }\end{array}$ & 4,490 & $\square$ \\
\hline 519 & Other Information Services & 8,040 & $\square$ \\
\hline 52 & Finance and Insurance & 245,440 & \\
\hline 521 & Monetary Authorities - Central Bank & & 冈 \\
\hline 522 & Credit Intermediation and Related Activities & 126,110 & 冈 \\
\hline 523 & $\begin{array}{l}\text { Securities, Commodity Contracts, and Other Intermediation and Related } \\
\text { Activities }\end{array}$ & 57,640 & 凶 \\
\hline 524 & Insurance Carriers and Related Activities & 58,190 & 叉 \\
\hline 5241 & Insurance Carriers & 34,070 & 区 \\
\hline 526 & Funds and Other Financial Vehicles & 3,500 & 叉 \\
\hline 53 & Real Estate and Rental and Leasing & 75,070 & \\
\hline 531 & Real Estate & 65,990 & $\nabla$ \\
\hline 5311 & Lessors of Real Estate & 16,900 & $\square$ \\
\hline 5312 & Offices of Real Estates Agents and Brokers & 35,510 & $\square$ \\
\hline 5313 & Activities Related to Real Estate & 13,580 & $\nabla$ \\
\hline 532 & Rental and Leasing Services & 8,880 & 凶 \\
\hline 5321 & Automotive Equipment Rental and Leasing & 5,040 & 叉 \\
\hline 5324 & Commercial and Industrial Machinery and Equipment Rental and Leasing & 1,560 & 区 \\
\hline 533 & Lessors of Non-Financial Assets & & \\
\hline 54 & Professional, Scientific and Technical Services & 326,970 & \\
\hline 5411 & Legal Services & 44,870 & $\square$ \\
\hline 5412 & Accounting, Tax Preparation, Bookkeeping and Payroll Services & 33,030 & $\square$ \\
\hline 5413 & Architectural, Engineering and Related Services & 55,730 & $\square$ \\
\hline 5414 & Specialized Design Services & 15,020 & $\square$ \\
\hline 5415 & Computer Systems Design and Related Services & 82,760 & $\square$ \\
\hline 5416 & Management, Scientific and Technical Consulting Services & 39,340 & $\square$ \\
\hline 5417 & Scientific Research and Development Services & 6,810 & $\square$ \\
\hline 5418 & Advertising and Related Services & 28,200 & $\square$ \\
\hline 5419 & Other Professional, Scientific and Technical Services & 21,220 & $\square$ \\
\hline 55 & Management of Companies and Enterprises & & \\
\hline 56 & $\begin{array}{l}\text { Administrative and Support, Waste Management and } \\
\text { Remediation Services }\end{array}$ & 156,290 & \\
\hline 561 & Administrative and Support Services & 150,910 & $\square$ \\
\hline 562 & Waste Management and Remediation Services & 5,380 & 区 \\
\hline 61 & Educational Services & 215,790 & \\
\hline 6111 & Elementary and Secondary Schools & 133,480 & 囚 \\
\hline 6112 & Community Colleges and C.E.G.E.P.S & 14,120 & 哽 \\
\hline 6113 & Universities & 40,090 & 凶 \\
\hline 6114 & Business Schools and Computer and Management Training & & 区 \\
\hline 6115 & Technical and Trade Schools & & 叉 \\
\hline 6116 & Other Schools and Instruction & 26,880 & 凶 \\
\hline 6117 & Educational Support Services & & 国 \\
\hline
\end{tabular}




\begin{tabular}{|c|c|c|c|}
\hline 62 & Health Care and Social Assistance & 298,040 & \\
\hline 621 & Ambulatory Health Care Services & 87,280 & 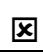 \\
\hline 622 & $\underline{\text { Hospitals }}$ & 93,970 & 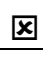 \\
\hline 623 & Nursing and Residential Care Facilities & 41,350 & 区 \\
\hline 624 & Social Assistance & 75,430 & 凶 \\
\hline 71 & Arts, Entertainment and Recreation & 75,860 & \\
\hline 7111 & Performing Arts Companies & 9,610 & $\mathbf{x}$ \\
\hline 7112 & Spectator Sports & 3,660 & 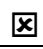 \\
\hline 7113 & Promoters (Presenters) of Performing Arts, Sports and Similar Events & 2,620 & $\square$ \\
\hline 7114 & $\begin{array}{l}\text { Agents and Managers for Artists, Athletes, Entertainers and Other } \\
\text { Public Figures }\end{array}$ & & $\square$ \\
\hline 7115 & Independent Artists, Writers and Performers & 14,180 & $\square$ \\
\hline 712 & Heritage Institutions & 3,700 & 凶 \\
\hline 713 & Amusement, Gambling and Recreation Industries & 41,370 & 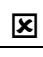 \\
\hline 72 & Accommodation and Food Services & 183,780 & \\
\hline 721 & Accommodation Services & 23,180 & 区 \\
\hline 722 & Food Services and Drinking Places & 160,600 & 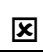 \\
\hline 81 & Other Services (except Public Administration) & 127,020 & \\
\hline 811 & Repair and Maintenance & 28,480 & 叉 \\
\hline 812 & Personal and Laundry Services & 40,000 & 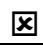 \\
\hline 813 & $\begin{array}{l}\text { Religious, Grant-Making, Civic, and Professional and Similar } \\
\text { Organizations }\end{array}$ & 34,580 & $\square$ \\
\hline 814 & Private Households & 23,950 & 凶 \\
\hline 91 & Public Administration & 112,880 & \\
\hline 911 & Federal Government Public Administration & 20,400 & $\nabla$ \\
\hline 912 & Provincial and Territorial Public Administration & 44,190 & $\square$ \\
\hline 913 & Local, Municipal and Regional Public Administration & 46,700 & $\square$ \\
\hline 914919 & Aboriginal Public Administration & 1,590 & $\square$ \\
\hline
\end{tabular}




\section{References}

Andrew, C., Hiley, N., Liu, P., Mattinson, A., Millar, S. Miller, P., Petch, Z., \& Shakya Singh, N. (2014). Making Industry Work - Attraction \& Accommodation of Employment Growth into Designated Employment Areas within the GGH. [PDF].

Botsman, R., \& Rogers, R. (2010). What's mine is yours. The Rise of Collaborative Consumption, Collins.

Brinkley, I. (2006). Defining the knowledge economy. London: The work foundation, 19.

Cagnol, Rémy. (2013, June 4). Should the public sector fund coworking spaces? Deskmag. Retrieved from http://www.deskmag.com/en/public-sector-fund-coworking

Capdevila, I. (2013). Knowledge Dynamics in Localized Communities: Coworking Spaces as Microclusters. Available at SSRN 2414121.

City of Toronto. (January 2013). Collaborating for Competitiveness: A Strategic Plan for Accelerating Economic Growth and Job Creation in Toronto.

Creative Wallonia. (2015). Wallonia European Creative District Project. [Website] Retrieved March $10^{\text {th }}, 2015$ from http://www.creativewallonia.be/projets/wallonia-european-creativedistrict/le-projet.htm?lng =en

Deskmag, (2010, July) "9 to 5 group" - Coworking's first name. Deskmag. Retrieved from http://www.deskmag.com/en/9-to-5-group-coworking-first-name

Deskmag. (2013). First results of The $3^{\text {rd }}$ Global Coworking Survey. [PDF] Retrieved from https://communityjelly.files.wordpress.com/2012/11/3rdglobalcoworkingsurvey121108034918-phpapp02.pdf

Deskmag. (n.d.). The History of Coworking [Interactive Timeline]. Retrieved from http://www.tikitoki.com/timeline/entry/156192/The-History-Of-Coworking-Presented-By-Deskmag/

Foertsch, C. (2012). Deskmag 2nd Annual Global Coworking survey. DeskMag. [PDF] Retrieved from

https://postmediacalgaryherald2.files.wordpress.com/2013/05/coworking_survey_booklet. pdf

Forlano, L. (2011). Building the Open-Source City: Changing Work Environments for Collaboration and Innovation. In Foth, M. (Ed.), From social butterfly to engaged citizen: Urban informatics, social media, ubiquitous computing, and mobile technology to support citizen engagement (pp. 479-ZZZ). Cambridge, MA: MIT Press. 
Gansky, L. (2010). The mesh: Why the future of business is sharing. Penguin.

Gladwell, M. (2000). Designs for Working. Gladwell.com. Retrieved from http://gladwell.com/designs-for-working/

Gotvassli, K. Å. (2012). 10. Managing the new knowledge workers. Foundations of the Knowledge Economy: Innovation, Learning and Clusters, 176. In Westeren, K. I. (Ed.).

(2012). Foundations of the knowledge economy: innovation, learning and clusters. Edward Elgar Publishing, Cheltenham, UK.

Government of Ontario, Ministry of Infrastructure. (2006). Growth plan for the greater golden horseshoe, 2006. Queens Printer for Ontario.

Government of Ontario, Ministry of Infrastructure. (2014). 2014 Provincial Policy Statement. Queens Printer for Ontario.

Hospers, G. J. (2003). Creative cities: Breeding places in the knowledge economy. Knowledge, Technology \& Policy, 16(3), 143-162.

Hurry, C. J. P. (2012). The HUB Halifax: A Qualitative Study on Coworking. Unpublished master's project, St. Mary's University, Halifax, Nova Scotia.

Kenline. (2012) "Defining a Culture": The Paradigm Shift Toward a Collaborative Economy. Retrieved from:

http://www.academia.edu/2327744/Defining_a_Culture_The_Paradigm_Shift_Toward_a_Co llective_Economy

Land, C., Otto, B. and Böhm, S. (2012). Creative Community or Co-mutiny? Practices, positions and political potentials in coworking spaces', Paper presented at the 6th Art of Management and Organization Conference, University of York, 4th-7th September, 2012. Retrieved from

Manser, M. E., \& Picot, G. (1999). Self-employment in Canada and the United States. Perspectives on Labour and Income, 11(3), 37-44.

Matzler, K., Veider, V., \& Kathan, W. (2015). Adapting to the sharing economy. MIT Sloan Management Review, 56(2), 71-77.

MBO Partners. (2012). The State of Independence in America: Second Annual Report. Retrieved from http://info.mbopartners.com/rs/mbo/images//2012MBO_Partners_State_of_Independence_Report.pdf

MBO Partners. (2014). 2014 State of Independence in America Report. Retrieved from http://info.mbopartners.com/rs/mbo/images/2014MBO_Partners_State_of_Independence_Report.pdf 
Moriset, B. (2014). Building new places of the creative economy: The rise of coworking spaces. Paper presented at the 2nd Geography of Innovation International Conference 2014, Utrecht, The Netherlands. Retrieved from https://halshs.archives-ouvertes.fr/halshs00914075

Neuman, W. L. (2006). Social research methods: Qualitative and quantitative approaches. 6th Ed. Pearson Education Inc.

Parrino, L. (2013). Coworking: assessing the role of proximity in knowledge exchange. Knowledge Management Research \& Practice, pp. 1-11.

Pearce-Neudorf, J. (2014). Collaborative Innovation: A shared discourse within Phnom Penh's coworking community? Unpublished master's thesis, Malmö University, Malmö, Sweden.

Polèse, M. (2010). The wealth and poverty of regions: Why cities matter. University of Chicago Press.

Poverty and Employment Precarity in Southern Ontario (PEPSO). (2013). It's more than poverty: employment precarity and household well-being. Retrieved from http://www.unitedwaytoronto.com/document.doc?id=91

PwC \& Urban Land Institute. (2014). Emerging Trends in Real Estate ${ }^{\circ}$. Washington, DC, PwC and the Urban Land Institute.

Spinuzzi, C. (2012). Working alone together coworking as emergent collaborative activity. Journal of Business and Technical Communication, 26(4), 399-441.

Surman, T. (2013). Building Social Entrepreneurship through the Power of Coworking. Innovations: Technology, Governance, Globalization, 8(3-4), 189-195.

The Values of Open Coworking. (n.d.) Retrieved 2014, October 14 from http://wiki.coworking.com/w/page/67817489/The\%20Values\%20of\%200pen\%20Coworking Weeks, L.C. (2013, April). "Green Coworking: How Ecofriendly Coworking Spaces Can Look". Deskmag. Retrieved from http://www.deskmag.com/en/green-coworking-how-ecofriendlycoworking-space-can-look-784

Wright, 2010. City of Toronto Official Plan (consolidated 2010). 